\title{
The Impact of the Banking Sector on Economic Structure and Growth
}

\author{
Jittima Tongurai* \\ Graduate School of Business Administration, Kobe University \\ 2-1, Rokkodai, Nada, Kobe 657-8501, Japan \\ Tel: +81 78803 6941; Fax: +81 788036941 \\ Email: tongurai@people.kobe-u.ac.jp \\ Chaiporn Vithessonthi \\ Sunway University Business School, Sunway University \\ No. 5, Jalan Universiti, Bandar Sunway, 47500 Selangor Darul Ehsan, Malaysia \\ Tel: +6 037491 8622; Fax: +6 0356358633 \\ Email: chaipornv@sunway.edu.my
}

*Corresponding author 


\title{
The Impact of the Banking Sector on Economic Structure and Growth
}

\begin{abstract}
In this paper, we study the impact of banking sector development on changes in economic structure and growth. We argue that banking sector development has differential effects on industrial sector development and agricultural sector development. We test whether economic structure and growth foster banking sector development. To test our hypotheses, we construct a panel sample of all countries in the world during 1960-2016. We find that banking sector development has a negative effect on agricultural sector development but exerts no effect on industrial sector development. The negative effect of banking sector development on agricultural sector development is only observed for countries with high degrees of banking sector development. Our results further show that agricultural sector development exerts a negative effect on banking sector development while industrial sector development has a positive effect on banking sector development.
\end{abstract}

JEL Classification: E4, F4, G2

Keywords: agricultural sector development; banking sector development; economic structure; economic growth; industrial sector development

\section{Introduction}

International capital mobility has a direct effect on economic growth and an indirect effect on growth via banking sector and financial development in general. Foreign capital inflows increase financial resources in the domestic economy, reduce firms' financial 
constraints, boost domestic investment, and subsequently promote economic growth (e.g., Bekaert et al., 2005; Edison et al., 2002; Herwartz and Walle, 2014b; Kose et al., 2009). Financial liberalization also influences growth through indirect channels by inducing financial development (i.e., banking sector and equity markets), which in the end increases economic growth (Herwartz and Walle, 2014b; Kose et al., 2009). International capital flows are important catalysts for domestic financial development, a key determinant of the extent of growth benefits that are associated with financial liberalization (e.g., Klein and Olivei, 2008). The relationship between financial markets development (hereafter "financial development") and economic growth has been the subject of interest to scholars and policy makers for many decades. Earlier studies (e.g., King and Levine, 1993b; Rajan and Zingales, 1998) document the positive effect of financial development on economic growth. Recent studies (e.g., Aizenman et al., 2015; Berkes et al., 2012; Cecchetti and Kharroubi, 2012; Cournède and Denk, 2015; Law and Singh, 2014; Sahay et al., 2015), however, find empirical evidence of nonlinearity of the finance-growth relationship. More importantly, the results on this relationship at both aggregate and disaggregate levels are mixed. Since prior studies on the finance-growth nexus at the disaggregate level are still limited and primarily focus on the question of whether financial development enhances the growth of industries that rely more on external finance, we re-examine the question of whether banking sector development drives changes in economic structure and growth at the disaggregate level.

The objectives of this paper are threefold. First, we attempt to empirically examine the effects of banking sector development on the development and growth of economic sectors (e.g., an industrial sector, an agricultural sector, and a services sector). In particular, we test whether a higher degree of banking sector development increases the development and growth of the industrial sector and the agricultural sector. If banking sector development increases the supply of funds (e.g., debt capital) in the economy and reduces firms' financial 
constraints, countries with higher degrees of banking sector development should have higher degrees of development for the industrial sector and/or the agricultural sector. If banking sector development is beneficial to industrial growth, higher levels of banking sector development should enlarge the size of the industrial sector and/or the agricultural sector. As we will discuss later, due to data unavailability, we have to exclude the services sector from our empirical analysis.

Second, based on empirical evidence on nonlinearity of the finance-growth relation (e.g., Berkes et al., 2012; Cecchetti and Kharroubi, 2012; Cournède and Denk, 2015; Law and Singh, 2014; Sahay et al., 2015), we argue that the relationship between banking sector development and industrial development is conditional upon the degree of banking sector development and other economic conditions. Because countries are more likely to focus on industrialization during the early stage of economic development, we expect the effects of banking sector development on industrial sector development and agricultural sector development to be positive. When the banking system becomes large and/or more advanced, the economy might have already evolved into a more knowledge-based economy. At the advanced stage of economic development, we expect the effects of banking sector development on agricultural sector development to be either negative or non-existent; however, we expect the effect of banking sector development on industrial sector development to still be positive. We empirically test these predictions and assess whether the effect of banking sector development on industrial development depends on the degree of banking sector development.

Third, we examine whether banking sector development drives industrial development or vice versa. Empirical evidence suggests that the relationship between financial development and economic growth is bidirectional (see e.g., Nyasha and Odhiambo, 2014). It is therefore important to test whether the development of real sectors (e.g., an industrial sector and an 
agricultural sector) affects the development of a financial sector. More specifically, we expect countries with higher degrees of real sector development (e.g., industrial sector development and agricultural sector development) to have higher degrees of banking sector development.

To address our research objectives, we construct an initial panel sample of all countries in seven regions: (1) East Asia and Pacific, (2) Europe and Central Asia, (3) Latin America and Caribbean, (4) Middle East and North Africa, (5) North America, (6) South Asia and (7) Sub-Sahara Africa. Our data covers the period of 1960-2016. We estimate a series of panel OLS regressions using three measures of banking sector development: namely, (1) BANK1, which is the share of domestic credit provided to the private sector by banks as a percentage of GDP, (2) BANK2, which is the share of domestic credit provided by the financial sector as a percentage of GDP, and (3) BANK3, which is the number of commercial bank branches (per 100,000 adults) ${ }^{1}$. With respect to economic structure, we focus on two sectors: (1) the industrial sector and (2) the agricultural sector. In this study, economic structure refers to the relative size of the industrial sector or the agricultural sector to the overall economy. We measure industrial sector development as the natural logarithm of the value added by the

\footnotetext{
${ }^{1}$ One limitation of measuring the banking sector development by the number of commercial bank branches is that, due to the advancement of technology, the number of bank branches, particularly in developed countries, may decline. Thus, it will be difficult to capture the effect of the banking sector development on industrial development and growth. We use this proxy in our analysis because this indicator has the largest number of observations $(N=1,955)$ among the 36 indicators of financial access in the Global Financial Development Database (June 2016) of the World Bank. Other indicators such as firms with a bank loan or line of credit, firms using banks to finance investment, firms using banks to finance working capital, investment financed by banks, and working capital financed by banks have 220, 290, 262, 290 and 262 observations, respectively.
} 
industry sector as a percentage of GDP. ${ }^{2}$ Agricultural sector development is measured as the natural logarithm of the value added by the agricultural sector as a percentage of GDP. ${ }^{3}$ The services sector ${ }^{4}$ has been excluded from the analysis because it also includes financial services; as a result, we have a simplified economic structure and analyzes the relationship between the banking sector, the industrial sector and the agricultural sector

Our key findings can be summarized as follows. First, we find empirical evidence to indicate that banking sector development has no effect on industrial sector development and a

${ }^{2}$ A full description of the variable provided by the World Bank Database is as follows: "Industry corresponds to ISIC divisions 10-45 and includes manufacturing (ISIC divisions 15-37). It comprises value added in mining, manufacturing (also reported as a separate subgroup), construction, electricity, water, and gas. Value added is the net output of a sector after adding up all outputs and subtracting intermediate inputs. It is calculated without making deductions for depreciation of fabricated assets or depletion and degradation of natural resources. The origin of value added is determined by the International Standard Industrial Classification (ISIC), revision 3.”

${ }^{3}$ A full description of the variable provided by the World Bank Database is as follows: "Agriculture corresponds to ISIC divisions 1-5 and includes forestry, hunting, and fishing, as well as cultivation of crops and livestock production. Value added is the net output of a sector after adding up all outputs and subtracting intermediate inputs. It is calculated without making deductions for depreciation of fabricated assets or depletion and degradation of natural resources. The origin of value added is determined by the International Standard Industrial Classification (ISIC), revision 3. Note: For VAB countries, gross value added at factor cost is used as the denominator."

${ }^{4}$ A full description of the variable provided by the World Bank Database is as follows: "Services correspond to ISIC divisions 50-99 and they include value added in wholesale and retail trade (including hotels and restaurants), transport, and government, financial, professional, and personal services such as education, health care, and real estate services. Also included are imputed bank service charges, import duties, and any statistical discrepancies noted by national compilers as well as discrepancies arising from rescaling. Value added is the net output of a sector after adding up all outputs and subtracting intermediate inputs. It is calculated without making deductions for depreciation of fabricated assets or depletion and degradation of natural resources. The industrial origin of value added is determined by the International Standard Industrial Classification (ISIC), revision 3.” 
negative effect on agricultural sector development. This set of findings implies that banking sector development can explain changes in economic structure in the sense that as the banking sector further develops, the relative importance of the agricultural sector declines. In addition, banking sector development has a negative effect on industrial sector growth but exerts no effect on the growth of the agricultural sector. Interestingly, these results seem to suggest that the agricultural sector is not dependent on banking sector development.

Second, we find that the effect of banking sector development on agricultural sector development appears to be conditional on the degree of banking sector development. More specifically, the negative effect of the banking sector development on agricultural sector development is only observed for countries with high degrees of banking sector development.

Last but not least, we document that both agricultural sector growth and industrial sector growth have a positive effect on banking sector development; however, agricultural sector development exerts a negative effect on banking sector development while industrial sector development has a positive effect on banking sector development.

Overall, our results point to the notion that the relationship between banking sector development and industry-level economic development and growth is generally onedirectional. That is, the development and growth of industrial sector and agricultural sector generally drives banking sector development.

Our study contributes to the finance-growth research in two important ways. First, we provide empirical evidence on the effects of banking sector development on economic structure and growth at the industry level (i.e., the industrial sector and the agricultural sector). Our industry-level evidence, to some extent, addresses the mixed results in the literature. That is, prior studies show that the relationship between financial development and economic growth is inconclusive. The mixed results might be due to the fact that the impact of financial development on economic growth varies across industries. Our findings show 
that the effect of banking sector development indeed varies across the two industries. Second, while there is a growing body of literature on the effect of economic growth on financial development, our findings shed new light by decomposing economic growth into industrylevel growth and showing that both agricultural sector growth and industrial sector growth drive banking sector development.

The rest of the paper is organized as follows. In Section 2, we review literature on the finance-growth nexus, focusing on studies relating to the relationship between banking sector development and industrial growth. Based on empirical evidence in prior studies, hypotheses are proposed for empirical testing. In Section 3, we describe our data, variables, and research methodology. We report and discuss empirical results in Section 4. Section 5 concludes the paper.

\section{Banking sector development, economic structure and growth}

\subsection{Literature review}

The relationship between financial development and economic growth has been investigated extensively in literature. In this paper, we define financial development in a broader sense, covering, banking sector development and financial sector development. We measure banking sector development (1) in terms of how much the banking sector can provide credit to the private sector as measured by the share of domestic credit to the private sector by banks as a percentage of GDP, (2) banking sector development in terms of financial access as measured by the number of commercial bank branches per 100,000 adults. We likewise measure financial sector development in terms of the overall financial system's ability to provide credit, as measured by the share of domestic credit provided by the financial sector as a percentage of GDP. 
On the one hand, financial development benefits the real economy by increasing efficiency of savings mobility and resource allocation to productive sectors (Greenwood et al., 2010; King and Levine, 1993b). Increasing the efficiency of a financial sector tends to reduce agency costs (Aghion et al., 2005) and promote risk-sharing in the economy (Bencivenga and Smith, 1991), thereby enhancing economic growth. Financial development, however, may have an adverse effect on economic growth if it increases volatility of the real output $^{5}$ (Huang et al., 2014), raises systemic risk (Allen and Carletti, 2006; Gennaioli et al., 2012; Wagner, 2007) and/or induces bubbles and crises (Zeira, 1999).

Earlier studies (e.g., King and Levine, 1993b; Levine et al., 2000; Rajan and Zingales, 1998) largely capture the positive effects of financial development on economic growth. The nonlinearity of the finance-growth nexus is increasingly evident in more recent studies (e.g., Aizenman et al., 2015; Berkes et al., 2012; Cecchetti and Kharroubi, 2012; Cournède and Denk, 2015; Law and Singh, 2014; Sahay et al., 2015). Analyzing a panel sample for 101 developed and developing countries over the period 1970-2010, Ductor and Grechyna (2015) show that there is a trade-off between financial and real sector growth. The relationship between financial development and economic growth is affected by the development of the real sector of the economy. When credit expansion is not followed by the expansion of the demand for funds by the productive sectors in the economy, the likelihood of funds being

\footnotetext{
${ }^{5}$ Manganelli and Popov (2015) assert that the effect of finance on the output variability depends on whether monetary or real shocks are at play and on whether the real shocks are due to shifts in credit demand or in credit supply. They find that, for 28 OECD countries over the period 1970-2007, developed financial markets reduce long-term volatility. Larrain (2006) finds empirical evidence suggesting that financial development lowers output volatility in manufacturing industries with high external dependence and liquidity needs. Meanwhile, Beck et al. (2006) find no correlation between financial development and long-term volatility.
} 
allocated to risky investments would increase and lead to lower economic growth or even financial crises.

The banking system is an important channel through which financial development exerts an effect on economic growth. The role of a banking sector is particularly important for small economies and developing countries where bond and equity markets are underdeveloped. Many firms highly depend on bank loans as a primary (or only) source of external finance (Chinn and Ito, 2005; Cline, 2015). Given the important role of banks in mobilizing savings to productive investment opportunities and in exerting sound corporate governance, banking sector development is crucial for economic growth.

The development of a banking sector (hereafter "banking sector development") will have a positive effect on economic growth if it lessens financial constraints of firms and increases the efficiency of fund allocation to firms with valuable investment opportunities. Empirical evidence (Islam and Mozumdar, 2007; Love, 2003) suggest that higher levels of financial development reduce firms' financial constraints. When the degree of financial development is high, firms should be able to finance their investment at the appropriate cost of capital. With better access to financing and more efficient allocation of funds to higher productive uses, banking sector development is expected to promote economic activities and growth.

Prior studies have documented a positive impact of banking sector development on output growth. For example, Beck et al. (2000) find that private credits (i.e., the credits by financial intermediaries to the private sector) is closely associated with economic development, primarily because of the externalities of bank performance to non-financial industries. Using a panel data of 138 countries during 2002-2009, Gimet and Lagoarde-Segot (2012) find that inter-bank competition, appropriate macro-prudential safeguards, capital market development, adequate civil rights and support to entrepreneurship can strengthen the linkages between banks and economic development, and are important features for improving 
the ability of banks to provide increased credit flows to the private sector and to enhance financial inclusion for the poor.

Amongt the large number of studies (Bremus and Buch, 2017; Cournède and Denk, 2015; Herwartz and Walle, 2014a; Samargandi et al., 2015) on financial development, prior studies on the relationship between financial development and economic growth at the disaggregate level are sparse. Due to differences in the characteristics of each economic sector (e.g., the industrial sector and the agricultural sector), the effect of financial development on economic growth is expected to vary across industrial sectors. This idea is supported in part by prior studies. For instance, Rajan and Zingales (1998) find that industries more dependent on external finance grow faster in countries with higher levels of financial development. Likewise, Beck and Levine (2002) find that greater financial development accelerates the growth of financially dependent industries. Liu et al. (2014) find that industrial sectors that rely more on external finance grow faster in countries with a higher level of financial development. More specifically, they find that, for a given level of external dependence, an increase in financial depth by one percentage point (as a proportion of GDP) leads to an increase in the real growth rate of value added of that industry by between 0.046 and 0.058 percentage points. Studying the effect of financial market structure (i.e., a bank-based financial system versus a market-based financial system) on growth, Kim et al. (2016) find that industries dominated by small firms grow faster in a country with a more bank-based financial system. Similarly, Pang and Wu (2009) find that bank performance plays an important role for industries that are more reliant on external finance. In a recent study, Mirzaei and Moore (2016) find that the impact of credit provided by the banking sector on industry growth (i.e., the growth of 42 non-oil industry sub-sectors) is positive and statistically significant at the $10 \%$ level for the case of Qatar during 2000-2006, suggesting that credit allocation of banks (i.e. quantity of finance) may matter for industrial growth. 
They find that increase in credit volumes alone does not stimulate growth, but competition, efficiency and stability of the banking sector contribute significantly to industrial growth. On the contrary, investigating 28 manufacturing industries in 30 provinces of mainland China, Lin et al. (2015) find that a correlation between banking sector development and industrial growth is negative.

\subsection{Hypothesis development}

Building upon the above discussion and the results of prior studies (e.g., Beck et al., 2000; Ductor and Grechyna, 2015; Kim et al., 2016; Mirzaei and Moore, 2016; Pang and Wu, 2009) that provide empirical evidence for the positive effect of banking sector development on industrial and economic growth, we argue that the effects of banking sector development on economic growth at an industry level are conditional on financial resource allocation to foster the growth of the industry. A significant role of the financial sector in economic development is the allocation of capital to investment activities with highest returns (Greenwood and Smith, 1997; King and Levine, 1993b). As a more advanced financial system tends to have a higher degree of financial allocation efficiency (Greenwood et al., 2010), funds will be allocated more to industries with better growth prospects and less to industries with poorer growth prospects. That is, an industry with greater investment opportunities is more likely to have a higher growth and thus is expected to benefit more from financial development. An industry with weaker investment opportunities is more likely to experience difficulties in obtaining additional funds for investment when financial development further improves.

The role of the banking sector in promoting industrialization and economic development has been studied in the past (see, e.g., Da Rin and Hellmann, 2002; King and Levine, 1993a; Levine, 1997; Rajan and Zingales, 1998; Rioja and Valev, 2004). As an economic structure 
tends to become increasingly industrialized when the economy develops, the contribution of financial development to industrial development and growth is expected to be different at various stages of economic development. We therefore expect banking sector development to have differential effects on the economic structure (e.g., the relative importance of the industrial sector, the agricultural sector and the services sector) and sectoral growth. More specifically, we expect banking sector development to strengthen the development of the industrial sector, the agricultural sector and the services sector differently. If banking sector development affects the industrial sector, the agricultural sector and the services sector differently, we would observe changes in the relative importance of these sectors in the economy when a banking sector further develops.

Suppose that there are two sectors, namely: an agricultural sector and an industrial sector. A country relatively more endowed with labor and/or natural resources is more likely to first develop the agricultural sector. ${ }^{6}$ It will subsequently develop the manufacturing sector. If a country follows these simple sequential development steps, as a banking sector further develops, it is expected to observe a shift in financial resource allocation between the two sectors. Assume that the agricultural sector, by its nature, is less likely to further develop when it reaches a certain level (e.g., the advanced stage of the agricultural industry) and that the manufacturing sector has better investment opportunities than the agricultural industry. Then, we expect banking sector development to start having a negative effect on the agricultural industry's growth at the moderate or high degree of banking sector development. At a low/moderate degree of banking sector development, we expect the effect of banking sector development on the manufacturing sector to be positive. We expect banking sector development to have a negative effect on the traditional (or labor-intensive) manufacturing

\footnotetext{
${ }^{6}$ In a theory of economic development, countries first develop the agricultural sector and later expand to the industrial sector development (Ranis and John, 1961).
} 
sector and a positive effect on the knowledge-intensive manufacturing sector at the high degree of banking sector development.

Consider a country in the early stage of economic development with a small banking sector and trivial capital markets. During the early stage of economic development where all real sectors are underdeveloped, it is more likely that the agricultural, industrial and services sectors would all benefit from the advancement in the banking sector. However, it is also possible that there would be the negative impact of banking sector development on the services sector during the early period of economic development because most countries tend to emphasize more on industrial sector development and thus are more likely to channel a disproportionately large amount of resources to the industrial sector. To finance and support new investment activities in the economy, the banking system must naturally become larger. ${ }^{7}$ During a period of the growing banking system, the industrial sector grows and becomes more modernized, suggesting that the effect of banking sector development on industrial sector development should be positive at the moderate level of banking sector development. During this period, economic development is likely to focus on industrialization. Financial allocation to agricultural sector could be lessen, suggesting that the effect of banking sector development on agricultural sector development should be either negative or no longer exist.

At a later stage of banking sector development (or when the banking system becomes large), it is more likely that the economy has already evolved and moved towards a more service-based economy (e.g., moving away from the traditional labor-intensive-based

7 Greenwood and Smith (1997) investigate theoretically the relationship between financial markets and economic development. They argue that the costs of financial market formation require that financial market development follows a period of real sector development. Financial markets will promote capital allocation to the most productive investment, and thus the development of financial markets will subsequently enhance the real sector growth. 
industrial sectors towards the knowledge-based industrial sectors). Financial allocation will be directed away from the labor-intensive-based industrial sectors to the knowledge-based industrial sectors, suggesting that the effect of banking sector development on the laborintensive-based industrial sector development should be either negative or no longer exist. At the advanced stage of economic development, the influence of banking sector development on the agricultural sector should be neutral or negative because the traditional labor-intensive agricultural sector has already been modernized and is unlikely to develop much further unless there are major technological breakthroughs in the agricultural industry. During the more advanced stage of economic development and/or the higher degree of banking sector development, we would still observe the positive impact of banking sector development on the knowledge-based industrial sectors. Figures 1 and 2 present our predictions.

\section{(INSERT FIGURE 1 ABOUT HERE)}

In summary, we expect the effect of banking sector development on industrial sector development to be positive for countries with low levels of banking sector development and negative for countries with high levels of banking sector development. We expect the effect of banking sector development on agricultural sector development to be positive for countries with low levels of banking sector development and negative for countries with high levels of banking sector development. Last but not least, we expect the effect of banking sector development on knowledge-based industrial sector development to be negative for countries with low levels of banking sector development and positive for countries with high levels of banking sector development. We therefore propose the following hypotheses. 
Hypothesis 1: The effect of banking sector development on industrial sector development is conditional on the degree of banking sector development. More specifically, the impact of banking sector development on industrial sector development should be positive (negative) for countries with low (high) degrees of banking sector development.

Hypothesis 2: The effect of banking sector development on agricultural sector development is conditional on the degree of banking sector development. More specifically, the impact of banking sector development on agricultural sector development should be positive (negative) for countries with low (high) degrees of banking sector development.

We now focus on the possibility that economic activities drive banking sector development. Generally speaking, lending activities of banks are susceptible to economic cycles. For instance, credit booms are associated with periods of economic expansion and subsequently reverse during economic downturns (Mendoza and Terrones, 2008). More specifically, in periods of economic expansion, the financial sector, particularly the banking sector, tends to extend a considerable amount of credits to the private sector. The recessionary pressures from an economic downturn that increases the level of banks' nonperforming loans (NPLs) are likely to force banks to contract their credit extension. Capital adequacy and regulatory supervision force banks to shrink their credit extension even further. Building upon this line of reasoning, we argue that banking sector development can be influenced by the development and growth of the real sectors (e.g., the industrial sector, the agricultural sector and the services sector). Prior studies have documented that the relationship between financial development and economic growth is bidirectional. For example, Nyasha and Odhiambo (2014) provide a summary of empirical studies on this matter. In line with the findings in prior literature, we argue that the economic structure and 
real sector growth affect the development of a banking sector. We propose the following hypotheses.

Hypothesis 3: The development and growth of the industrial sector positively affects banking sector development. More specifically, countries with higher degrees of industrial sector development tend to have higher degrees of banking sector development. Likewise, countries with higher degrees of industrial sector growth tend to have higher degrees of banking sector development.

Hypothesis 4: The development and growth of the agricultural sector positively affects banking sector development. More specifically, countries with higher degrees of agricultural sector development tend to have higher degrees of banking sector development. Likewise, countries with higher degrees of agricultural sector growth tend to have higher degrees of banking sector development.

\section{Data and methodology}

\subsection{Data and sample}

Our initial sample consists of all countries in seven regions: (1) East Asia and Pacific, (2) Europe and Central Asia, (3) Latin America and Caribbean, (4) Middle East and North Africa, (5) North America, (6) South Asia and (7) Sub-Sahara Africa ${ }^{8}$. We retrieve annual macroeconomic data over the period 1960-2016 from Datastream and World Databank of the World Bank. Given that all times series are not available for all countries for all years in the sample period, we have an unbalanced sample of country-year observations.

\footnotetext{
${ }^{8}$ We follow World Bank with respect to assigning countries into one of the seven regions.
} 
As discussed in the previous section, we focus on two industry-level sectors of a country: (1) an industrial sector and (2) an agricultural sector. Initially, we consider three industrylevel sectors of the country by adding a services sector. However, banking/financial services have been included in the services sector. Therefore, we could not analyze the effect of banking sector development on the services sector due to this data limitation. We measure industrial sector development by the natural logarithm of the value added by the industry sector as a percentage of GDP. We use the natural logarithm of the value added by the agricultural sector as a percentage of GDP to proxy for agricultural sector development.

We use three measures to proxy for banking sector development. First, BANK1 is the share of domestic credit to the private sector by banks as a percentage of GDP. ${ }^{9}$ This variable includes only credit issued to the private sector by depository financial institutions (i.e., banks). The measure is considered a good indicator for banking sector development (e.g., Berkes et al., 2012; Ductor and Grechyna, 2015). Second, BANK2 is the share of domestic credit provided by the financial sector as a percentage of GDP. ${ }^{10}$ This measure has been used

\footnotetext{
${ }^{9}$ A full description of this variable provided by the World Bank Database is as follows: "Domestic credit to private sector by banks refers to financial resources provided to the private sector by other depository corporations (deposit taking corporations except central banks), such as through loans, purchases of nonequity securities, and trade credits and other accounts receivable, that establish a claim for repayment. For some countries these claims include credit to public enterprises.”

${ }^{10}$ A full description of this variable provided by the World Bank Database is as follows: "Domestic credit provided by the financial sector includes all credit to various sectors on a gross basis, with the exception of credit to the central government, which is net. The financial sector includes monetary authorities and deposit money banks, as well as other financial corporations where data are available (including corporations that do not accept transferable deposits but do incur such liabilities as time and savings deposits). Examples of other financial corporations are finance and leasing companies, money lenders, insurance corporations, pension funds, and foreign exchange companies.”
} 
extensively in the literature (e.g., Ductor and Grechyna, 2015; Eichengreen et al., 2011) and is considered a good indicator for financial sector development compared to other alternatives. While these two measures are frequently used in the literature, both measures primarily indicate the relative size of the banking system. We therefore use BANK3, which is the number of commercial bank branches (per 100,000 adults), ${ }^{11}$ to measure banking sector development in terms of financial access (Sahay et al., 2015). A country with a more advanced banking system should have more commercial bank branches to serve customers. We compute the natural logarithm of all three banking sector development indicators. More specifically, LNBANK1 is the natural logarithm of BANK1. LNBANK2 is the natural logarithm of BANK2. LNBANK3 is the natural logarithm of BANK3. It is important to note that data on BANK3 is only available for the sample period 2001-2015.

\subsection{Empirical methodology}

We primarily use ordinary least squares (OLS) to assess the effects of banking sector development on industrial sector development and agricultural sector development. As industrial sector development and agricultural sector development may be persistent, we estimate a series of the following baseline panel dynamic OLS regressions.

$$
\begin{aligned}
& \operatorname{INDDEV}_{i, t}=\alpha+\beta_{1} \operatorname{INDDEV}_{i, t-1}+\beta_{2} \text { BANK }_{i, t-1}+\gamma \mathbf{C O N}_{i, t-1}+\eta_{i}+v_{t}+\varepsilon_{i, t}, \\
& A G R D E V_{i, t}=\alpha+\beta_{1} A G R D E V_{i, t-1}+\beta_{2} B A N K_{i, t-1}+\gamma \mathbf{C O N}_{i, t-1}+\eta_{i}+v_{t}+\varepsilon_{i, t},
\end{aligned}
$$

\footnotetext{
${ }^{11}$ A full description of this variable provided by the World Bank Database is as follows: "Commercial bank branches are retail locations of resident commercial banks and other resident banks that function as commercial banks that provide financial services to customers and are physically separated from the main office but not organized as legally separated subsidiaries."
} 
where $i$ and $t$ index country $i$ and time $t$, respectively. INDDEV $V_{i, t}$ is the indicator of industrial sector development; $A G R D E V_{i, t}$ is the indicator of agricultural sector development; $B A N K_{i, t}$ denotes the indicator of banking sector development (e.g., BANK1, BANK2 and BANK3); $\mathbf{C O N}_{i, t}$ is a vector of country-level control variables; $\eta_{i}$ is a country-fixed effect; $v_{t}$ is a period-fixed effect, and $\varepsilon_{i, t}$ is the zero-mean disturbance term. Standard errors that are adjusted for heteroskedasticity and serial correlation are clustered at the country level. We include a one-period lag of the dependent variable as a right-hand side variable to control for possible persistence in industrial sector development or agricultural sector development.

We include a set of control variables in our panel OLS regressions. Unless stated otherwise, we include country fixed-effects to control for omitted time-invariant country characteristics and period fixed-effects to control for any unobserved time-variant effects. We rely on Hausman tests to indicate whether fixed-effects estimates are preferred to randomeffects estimates. We lag all right-hand side variables by one period to deal with reversecausality concerns and the endogeneity problem.

We add a set of control variables in our regression to control for the time-varying economic conditions on industrial sector development. These variables include (1) real GDP per capita (GDP), (2) GDP growth ( $\triangle \mathrm{GDP})$, measured by the first difference in the natural logarithm of real GDP per capita, (3) the net foreign asset (FAGDP), measured by the net foreign asset as a percentage of GDP, (4) government spending (GOVGDP), measured by the final consumption expenditures of general government as a percentage of GDP, (5) inflation (INF), measured by the GDP deflator in annual percentage, (6) interest rate (INT), measured by the real interest rate in percentage, (7) investment (INVGDP), measured by gross fixed capital formation as a percentage of GDP, and (8) trade openness (TRADE), measured by the total trade as a percentage of GDP. 
To test Hypotheses 3 and 4, we estimate several versions of the following baseline panel dynamic OLS regression.

$$
B A N K_{i, t}=\alpha+\beta_{1} B A N K_{i, t-1}+\beta_{2} I N D D E V_{i, t-1}+\beta_{3} A G R D E V_{i, t-1}+\gamma \mathbf{C O N}_{i, t-1}+\eta_{i}+v_{t}+\varepsilon_{i, t},
$$

where all variables are defined as before. We include a one-period lag of the dependent variable as a right-hand side variable to control for potential persistence in banking sector development. Country- and year-fixed effects are included in all regressions.

\section{Empirical results and discussions}

\subsection{Descriptive statistics and univariate analysis}

Table 1 reports descriptive statistics for key variables in the full sample. To minimize the effects of outliers and possible recording errors, we winsorize all variables at the 5th and 95th quantiles. We are concerned with the possibility that LNBANK1 and LNBANK2 may measure the same construct as a correlation between LNBANK1 and LNBANK2 is high and statistically significant $(r=0.99, p$-value $<0.01)$, implying that these two variables must separately enter the regression to avoid the multicollinearity problem. We also notice that inflation (INF) and real interest rate (INT) are highly correlated $(r=-0.45, p$-value $<0.01)$. As a consequence, we decide to use only real interest rate in our regression analyses, given that real interest rate can be used as a proxy for monetary policy; however, the availability of data on real interest rates for our sample is very limited prior to 1970.

As our sample includes a large number of countries and long time series, we perform panel unit root tests for each time series variable in Table 1 using the Levin, Lin and Chu test and the Augmented-Dickey-fuller Fisher test with lag length selected by the Akaike Info 
Criterion (AIC). We find no presence of unit roots for their levels and first differences for all variables but BANK1 and BANK2, given that the test results reject the null hypothesis of the presence of a unit root. It is important to note that the tests fail to reject the null hypothesis of the presence of a unit root in the level for BANK1 and BANK2; therefore, we use the natural logarithm of the banking sector development measures in the analysis. We also perform Pedroni $(1999,2004)$ and Kao (1999) panel cointegration tests with lag length selected by the Schwarz Info Criterion (SIC). The results fail to reject the null hypothesis of no cointegration at the $5 \%$ level.

\section{(INSERT TABLE 1 ABOUT HERE)}

\subsection{The effects of banking sector development on industrial sector development and agricultural sector development}

In this section, we estimate a series of panel OLS regressions to empirically test whether banking sector development affects industrial sector development and agricultural sector development. Since Hausman tests suggest that fixed-effects models are preferred to randomeffects models, we estimate the panel OLS regressions that include the country- and yearfixed effects.

Columns (1), (2) and (3) of Table 2 report panel OLS regression results of industrial sector development, while columns (4), (5) and (6) of Table 2 present simple panel dynamic OLS regression results of industrial sector development. The dependent variable is LNINDDEV, which is the natural logarithm of the value added by the industry sector as a percentage of GDP. 
As discussed earlier, since banking sector development measures are highly correlated, we enter LNBANK1, LNBANK2 and LNBANK3 separately in columns (1), (2) and (3). Looking across columns (1), (2) and (3), we find that the coefficients on all banking sector development (i.e., LNBANK1, LNBANK2 and LNBANK3) are not statistically significant. These results suggest that banking sector development has no effect on industrial sector development after controlling for a large set of country-level variables. We observe that most estimated coefficients on other variables have the expected sign. For example, the coefficient on GDP is positive and statistically significant, indicating that more advanced countries tend to have a higher degree of industrial sector development. Investment (INVGDP) and trade openness (TRADE) have a positive effect on industrial sector development while government spending (GOVGDP) and the real interest rate (INT) have a negative effect on industrial sector development.

As industrial sector development might be persistent, we estimate simple panel dynamic OLS regressions by including a one-year lag of the dependent variable as a right-hand side variable in columns (4), (5) and (6). The coefficient on lagged industrial sector development is positive and statistically significant, indicating persistence in industrial sector development. Results in columns (4), (5) and (6) show that the coefficients on all three banking sector development measures are not statistically significant. Overall, our findings do not support the notion that banking sector development promotes industrial sector development.

(INSERT TABLE 2 ABOUT HERE)

(INSERT TABLE 3 ABOUT HERE) 
To test the effect of banking sector development on agricultural sector development, we estimate panel OLS regressions of agricultural sector development. The dependent variable is LNAGRDEV, which is the natural logarithm of the value added by the agricultural sector as a percentage of GDP. Columns (1), (2) and (3) of Table 3 report panel OLS regression results of agricultural sector development while columns (4), (5) and (6) present panel dynamic OLS regression results of agricultural sector development. Looking across columns (1) through (3), we find that the coefficients on LNBANK1 and LNBANK2 are negative and statistically significant, suggesting that banking sector development is negatively associated with agricultural sector development. We interpret these findings as empirical evidence to support the notion that banking sector development (or the size of the banking/financial system) weakens the level of contribution of the agricultural sector to the economy.

We find that LNBANK1 and LNBANK2 lose their statistical significance (i.e., the coefficients become statistically significant only at the $10 \%$ level) when lagged agricultural sector development is included as a right-hand side variable in columns (4), (5) and (6). Note that the coefficients on lagged agricultural sector development are positive and statistically significant, implying that agricultural sector development is persistent.

The findings in Tables 2 and 3 appear to suggest that the banking sector does not affect the relative importance of the industrial sector and the agricultural sector. In other words, banking sector development generally has no effect on industrial sector development and agricultural sector development for an average country.

\subsection{Are the effects of banking sector development nonlinear?}

To empirically test our predictions, we spilt our sample into (1) a sample of countries with low degrees of banking sector development and (2) a sample of countries with high 
degrees of banking sector development based on the cross-sectional median value of the banking sector development indicator (i.e., LNBANK1, LNBANK2 and LNBANK3). HBSD1 takes a value of one for country-year observations with the value of LNBANK1 larger than the cross-sectional median value of LNBANK1, and zero otherwise. HBSD2 takes a value of one for country-year observations with the value of LNBANK2 larger than the cross-sectional median value of LNBANK2. HBSD3 takes a value of one for countryyear observations with the value of LNBANK3 larger than the cross-sectional median value of LNBANK3. We estimate panel dynamic OLS regressions for all subsamples. When we use LNBANK1 (LNBANK2 or LNBANK3) as our proxy for banking sector development, we use HBSD1 (HBSD2 or HBSD3, respectively) to split the sample.

Table 4 reports simple panel dynamic OLS regression results of industrial sector development for the low and high banking sector development subsamples. The dependent variable is LNINDDEV, which is the natural logarithm of the value added by the industry sector as a percentage of GDP. We find that the coefficients on all banking sector development are not statistically significant. These results do not support Hypothesis 1, which predicts that the effect of banking sector development on industrial sector development varies with the degree of banking sector development.

\section{(INSERT TABLE 4 ABOUT HERE)}

(INSERT TABLE 5 ABOUT HERE)

Table 5 reports the results of simple panel dynamic OLS regression of agricultural sector development for the low and high banking sector development subsamples. The dependent variable is LNAGRDEV, which is the natural logarithm of the value added by the agricultural sector as a percentage of GDP. The results show that banking sector development has no 
effect on agricultural sector development for the low banking sector development subsamples but has a negative effect on agricultural sector development for the high banking sector development subsamples (see columns (2) and (4)). These findings support Hypothesis 2, which predicts that the effect of banking sector development on agricultural sector development varies with the degree of banking sector development.

In addition, we conduct several tests for non-linear effects of banking sector development. More specifically, we create six dummy variables based on the three banking sector development variables. First, we compute $\triangle \mathrm{BANK} 1$, which is the first difference in the natural logarithm of BANK1. Second, we compute two dummy variables: (1) POS_ABANK1 which takes a value of one if $\triangle \mathrm{BANK} 1$ is larger than zero, and zero otherwise, (2) NEG_ $\triangle \mathrm{BANK} 1$ which takes a value of one if $\triangle \mathrm{BANK} 1$ is smaller than zero, and zero otherwise. We repeat these procedures for all banking sector development measures (i.e. BANK2 and BANK3).

We add two interaction terms "LNBANK1 $\times$ POS_ABANK1" and "LNBANK1 $\times$ NEG_ABANK1" in the dynamic OLS regressions of agricultural sector development (LNAGRDEV) and industrial sector development (LNINDDEV). We repeat the same procedures for the other two banking sector development variables. To conserve space, we do not tabulate the results. We generally find that the coefficients on the interaction terms are statistically insignificant. These results suggest that the direction of the change in banking sector development does not asymmetrically affect agricultural sector development and industrial sector development.

4.4 The effects of banking sector development on industrial sector growth and agricultural sector growth 
Thus far, our main measure of industrial sector development and agricultural sector development mainly relies on the relative importance of the industrial sector or the agricultural sector to the overall economy (e.g., the value added by the industry sector as a percentage of GDP). In this section, we focus on the change in the size of the sector. More specifically, we measure industrial sector growth as the first difference in the natural logarithm of the real value added by the industry sector in USD. We follow this approach in computing the alternative measure for agricultural sector growth. By using these alternative measures, we would be able to test whether banking sector development changes the size of the industrial sector and the agricultural sector. Our primary rationale for using these measures is that although the banking sector might increase the size of the industrial sector, we could potentially observe the negative relationship between banking sector development and industrial sector development if the relative importance of the industrial sector falls (i.e., GDP grows at a higher rate than does the industrial sector). The same rationale applies for the agricultural sector.

Table 6 reports our panel OLS regressions of $\triangle$ INDSIZE, which is the first difference in the natural logarithm of the real value added by the industry sector in USD. Columns (1), (2) and (3) present the results of panel OLS regressions while columns (4), (5) and (6) report the results of simple panel dynamic OLS regression. As expected, GDP, GDP growth, the net foreign assets, and trade openness have a positive effect on industrial sector growth. Looking across all columns in Table 6, we find that banking sector development has a negative effect on industrial sector growth as the coefficient on LNBANK1 is negative and statistically significant at the 5\% level (see columns (1) and (4)). These results offer additional support to the notion that banking sector development is associated with industrial sector growth. 
(INSERT TABLE 7 ABOUT HERE)

Table 7 reports our panel OLS regressions of $\triangle$ AGRSIZE, which is the first difference in the natural logarithm of the real value added by the agricultural sector in USD. Columns (1), (2) and (3) present the results of panel OLS regressions while columns (4), (5) and (6) report the results of simple panel dynamic OLS regression. We find that GDP, GDP growth and trade openness have a positive effect on agricultural sector growth. Looking at the coefficients on banking sector development measures, we find that banking sector development has no effect on the growth rate of the agricultural sector. The results in Table 7 suggest that banking sector development exerts no influence on agricultural sector growth.

\subsection{Do economic structure and growth drive banking sector development?}

In this section, we address a question of whether the economic structure and growth affect banking sector development and test hypotheses 3 and 4 . In this paper, the economic structure refers to the relative importance of the industrial sector or the agricultural sector to the overall economy. Surprisingly, this question has rarely been touched upon in the literature. Some scholars (e.g., Lucchetti et al., 2001) have earlier argued that economic development helps push financial development. The idea that economic development drives banking sector development has been increasingly discussed because rapid growth in spite of financial underdevelopment is evident in many developing Asia, particularly in China. Thus far, empirical studies have been done mostly for less developed countries in Africa (i.e., Kenya, Zambia, and South Africa), China, and the Middle East and North Africa region. For more details of studies on causality of financial development to economic growth, see Nyasha and Odhiambo (2014). 
Table 8 reports the results of panel OLS regressions of banking sector development. LNBANK1 is the dependent variable in columns (1) and (4). LNBANK2 is the dependent variable in columns (2) and (5). LNBANK3 is the dependent variable in columns (3) and (6). Columns (1), (2) and (3) present the results of panel OLS regressions while columns (4), (5) and (6) report the results of simple panel dynamic OLS regression. We include both LNAGRDEV and LNINDDEV together in each of the six models.

The results show that LNAGRDEV has a negative effect on LNBANK1 (see columns (1) and (4)) and LNBANK2 (see columns (2) and (5)) while LNINDDEV has a positive effect on LNBANK1 (see column (4)) and LNBANK2 (see column (5)). These results imply that countries with higher degrees of agricultural sector development have lower degrees of banking sector development (measured as LNBANK1 and LNBANK2) and that countries with higher degrees of industrial sector development have higher degrees of banking sector development (measured as LNBANK1 and LNBANK2).

\section{(INSERT TABLE 8 ABOUT HERE)}

(INSERT TABLE 9 ABOUT HERE)

To test whether results shown in Table 8 remain robust after controlling for industry growth, we reestimate the specifications in Table 8 with lagged dependent variables by adding $\triangle \mathrm{AGRSIZE}$ and $\triangle \mathrm{INDSIZE}$ as the explanatory variable. We report the results in Table 9. In columns (1) and (2), the dependent variable is LNBANK1. The coefficients on $\triangle$ AGRSIZE and $\triangle$ INDSIZE are positive and statistically significant in both models, indicating that agricultural sector growth and industrial sector growth have a positive effect on banking sector development. Consistent with the results in columns (1) and (4) of Table 8, 
the coefficients on LNAGRDEV and LNINDDEV in column (2) of Table 9 are negative and positive, respectively.

In columns (3) and (4) of Table 9, the dependent variable is LNBANK2. The pattern of the results in columns (3) and (4) of Table 9 is also similar to that of columns (1) and (2) of Table 9, suggesting that agricultural sector growth and industrial sector growth have a positive effect on banking sector development and that agricultural sector development has a negative effect on banking sector development while industrial sector development has a positive effect on banking sector development.

In columns (5) and (6) of Table 9, the dependent variable is LNBANK3. We find that the coefficients on LNAGRDEV, LNINDDEV, and $\triangle$ AGRSIZE are statistically insignificant. The coefficient on $\triangle$ INDSIZE is negative and statistically significant at the $5 \%$ level. These results are consistent with the results in column (6) of Table 8.

Overall, the results in Tables 8 and 9 suggest that agricultural sector growth and industrial sector growth promote banking sector development. However, lower degrees of the relative importance of the agricultural sector would be associated with higher degrees of banking sector development while higher degrees of the relative importance of the industrial sector would be associated with higher degrees of banking sector development. Our results partially support hypotheses 3 and 4 .

\subsection{Addressing the endogeneity concern}

Because agricultural sector development and industrial sector development may be driven by country-level conditions that also affect banking sector development, we follow recent finance studies (see e.g., Bucă and Vermeulen, 2017; Deli and Hasan, 2017) and address endogenerity concerns by obtaining the new estimation results using the dynamic 
two-step panel generalized method of moments (GMM) technique. More specifically, we estimate a series of the following baseline dynamic two-step panel GMM models:

$$
\begin{gathered}
\operatorname{INDDEV}_{i, t}=\alpha+\beta_{1} \operatorname{INDDEV}_{i, t-1}+\beta_{2} \text { BANK }_{i, t-1}+\gamma \mathbf{C O N}_{i, t-1}+\eta_{i}+v_{t}+\varepsilon_{i, t}, \\
A G R D E V_{i, t}=\alpha+\beta_{1} A G R D E V_{i, t-1}+\beta_{2} B A N K_{i, t-1}+\gamma \mathbf{C O N}_{i, t-1}+\eta_{i}+v_{t}+\varepsilon_{i, t}, \\
B A N K_{i, t}=\alpha+\beta_{1} \text { BANK }_{i, t-1}+\beta_{2} I N D D E V_{i, t-1}+\beta_{3} A G R D E V_{i, t-1}+\gamma \mathbf{C O N}_{i, t-1}+\eta_{i}+v_{t}+\varepsilon_{i, t},
\end{gathered}
$$

where all variables are defined as earlier. Based on prior studies such as those of Arellano and Bond (1991), Athanasoglou et al. (2008), O’Connor and Rafferty (2012), and Ellul and Yerramilli (2013), we include a one-period lag of the dependent variable as the explanatory variable to account for persistence in industrial sector development, agricultural sector development or banking sector development. We use the first difference of the second lags of the same right-hand side variables as instruments. We first differentiate the regression equations so as to remove the unobserved cross-section effects. We use a standard two-step estimator with a White weighting matrix. In some specifications, we add period-fixed effects in the GMM regressions to control for unobserved time variant effects.

We conduct the Arellano-Bond test for the first- and second-order of autocorrelation in the first-differenced errors under the null of no serial correlation. We find that for almost all specifications, the $\operatorname{AR}(1)$ is statistically significant, but the $\operatorname{AR}(2)$ is not statistically significant. As a result, we are generally able to reject the null hypothesis of second-order auto correlation of the first differenced residuals. To test whether the instruments are valid, we conduct Hansen's $\mathrm{J}$ test for over-identifying restrictions, under the null of instrument validity. The tests of the GMM specifications show insignificant test statistics for Hansen Jstatistics of over-identifying restrictions, indicating that the instrument sets are valid. Taken 
together, the diagnostic tests suggest that the GMM estimation results do not suffer from the specification issue nor the instrument issue.

To conserve space, we do not tabulate the GMM results, which are available upon request. We find that the effect of banking sector development on agricultural sector development is negative but statistically insignificant. Likewise, the effect of banking sector development on industrial sector development is positive but statistically insignificant. In addition, we find that agricultural sector development has a negative effect on banking sector development (LNBANK1 and LNBANK2), while industrial sector development has a positive effect on banking sector development. These results are generally consistent with the panel OLS results.

\section{Conclusion}

It has often been argued that promoting banking and financial sectors is crucial for economic development. In this paper, we empirically test whether the relationship between banking sector development and industry-level development exists. More specifically, we focus on the impact of banking sector development on development and growth of two economic sectors: the industrial sector and the agricultural sector.

We argue that banking sector development has the differential effects on industrial sector development and agricultural sector development. If the presence of a more advanced banking system is a prerequisite for industrial sector development, developing countries should seek to modernize the banking system first. On the other hand, if the development of a banking sector follows the industrial development, a country will have to help facilitate the development of the industrial sector first. Therefore, we also test whether economic structure and growth foster banking sector development. 
We use a panel sample of all countries in seven regions (i.e., East Asia and Pacific, Europe and Central Asia, Latin America and Caribbean, Middle East and North Africa, North America, South Asia, and Sub-Sahara Africa) over the period 1960-2016 to empirically test our predictions. Our results show that banking sector development has a negative effect on agricultural sector development. However, this negative effect is only observed for countries with high degrees of banking sector development. We find that banking sector development has no effect on industrial sector development. Furthermore, we show that banking sector development has a negative effect on industrial sector growth and no effect on agricultural sector growth. Last but not least, we document that both agricultural sector growth and industrial sector growth have a positive effect on banking sector development; however, agricultural sector development exerts a negative effect on banking sector development while industrial sector development has a positive effect on banking sector development.

Taken together, our results point to the notion that the relationship between banking sector development and industry-level economic growth is generally one-directional. That is, the development and growth of industrial and agricultural sector drives banking sector development.

\section{References}

Aghion, P., Howitt, P., Mayer-Foulkes, D., 2005. The effect of financial development on convergence: Theory and evidence. The Quarterly Journal of Economics 120, 173222.

Aizenman, J., Jinjarak, Y., Park, D., 2015. Financial Development and Output Growth in Developing Asia and Latin America: A Comparative Sectoral Analysis., NBER Working Paper No. 20917. National Bureau of Economic Research, Cambridge, Massachusetts. 
Allen, F., Carletti, E., 2006. Credit risk transfer and contagion. Journal of Monetary Economics 53, 89-111.

Arellano, M., Bond, S., 1991. Some tests of specification for panel data: Monte Carlo evidence and an application to employment equations. The Review of Economic Studies 58, 277-297.

Athanasoglou, P.P., Brissimis, S.N., Delis, M.D., 2008. Bank-specific, industry-specific and macroeconomic determinants of bank profitability. Journal of International Financial Markets, Institutions and Money 18, 121-136.

Beck, T., Levine, R., 2002. Industry growth and capital allocation: Does having a market- or bank-based system matter? Journal of Financial Economics 64, 147-180.

Beck, T., Levine, R., Loayza, N., 2000. Finance and the sources of growth. Journal of Financial Economics 58, 261-300.

Beck, T., Lundberg, M., Majnoni, G., 2006. Financial intermediary development and growth volatility: Do intermediaries dampen or magnify shocks? Journal of International Money and Finance 25, 1146-1167.

Bekaert, G., Harvey, C.R., Lundblad, C., 2005. Does financial liberalization spur growth? Journal of Financial Economics 77, 3-55.

Bencivenga, V.R., Smith, B.D., 1991. Financial intermediation and endogenous growth. The Review of Economic Studies 58, 195-209.

Berkes, E.G., Panizza, U., Arcand, J.-L., 2012. Too Much Finance? International Monetary Fund.

Bremus, F., Buch, C.M., 2017. Granularity in banking and growth: Does financial openness matter? Journal of Banking \& Finance 77, 300-316.

Bucă, A., Vermeulen, P., 2017. Corporate investment and bank-dependent borrowers during the recent financial crisis. Journal of Banking \& Finance 78, 164-180. 
Cecchetti, S.G., Kharroubi, E., 2012. Reassessing the Impact of Finance on Growth, BIS Working Paper 381. Bank for International Settlements, Basel.

Chinn, M.D., Ito, H., 2005. What matters for financial development? Capital controls, institutions, and interactions, NBER Working Paper No.11370. National Bureau of Economic Research, Cambridge, Massachusetts.

Cline, W.R., 2015. The Financial Sector and Growth in Emerging Asian Economies, PIIE WP15-5. Peterson Institute for International Economics, Washington DC.

Cournède, B., Denk, O., 2015. Finance and Economic Growth in OECD and G20 Countries, OECD Economics Department Working Papers No. 1223. Organization for Economic Cooperation and Development, Paris, France.

Da Rin, M., Hellmann, T., 2002. Banks as Catalysts for Industrialization. Journal of Financial Intermediation 11, 366-397.

Deli, Y.D., Hasan, I., 2017. Real effects of bank capital regulations: Global evidence. Journal of Banking \& Finance 82, 217-228.

Ductor, L., Grechyna, D., 2015. Financial development, real sector, and economic growth. International Review of Economics \& Finance 37, 393-405.

Edison, H.J., Levine, R., Ricci, L., Sløk, T., 2002. International financial integration and economic growth. Journal of International Money and Finance 21, 749-776.

Eichengreen, B., Gullapalli, R., Panizza, U., 2011. Capital account liberalization, financial development and industry growth: A synthetic view. Journal of International Money and Finance 30, 1090-1106.

Ellul, A., Yerramilli, V., 2013. Stronger risk controls, lower risk: Evidence from U.S. bank holding companies. Journal of Finance 68, 1757-1803.

Gennaioli, N., Shleifer, A., Vishny, R., 2012. Neglected risks, financial innovation, and financial fragility. Journal of Financial Economics 104, 452-468. 
Gimet, C., Lagoarde-Segot, T., 2012. Financial sector development and access to finance. Does size say it all? Emerging Markets Review 13, 316-337.

Greenwood, J., Sanchez, J.M., Wang, C., 2010. Financing development: The role of information costs. American Economic Review 100, 1875-1891.

Greenwood, J., Smith, B.D., 1997. Financial markets in development, and the development of financial markets. Journal of Economic Dynamics and Control 21, 145-181.

Herwartz, H., Walle, Y.M., 2014a. Determinants of the link between financial and economic development: Evidence from a functional coefficient model. Economic Modelling 37, 417-427.

Herwartz, H., Walle, Y.M., 2014b. Openness and the finance-growth nexus. Journal of Banking \& Finance 48, 235-247.

Huang, H.-C., Fang, W., Miller, S.M., 2014. Does financial development volatility affect industrial growth volatility? International Review of Economics \& Finance 29, 307 320.

Islam, S.S., Mozumdar, A., 2007. Financial market development and the importance of internal cash: Evidence from international data. Journal of Banking \& Finance 31, 641-658.

Kao, C., 1999. Spurious regression and residual-based tests for cointegration in panel data. Journal of Econometrics 90, 1-44.

Kim, D.-H., Lin, S.-C., Chen, T.-C., 2016. Financial structure, firm size and industry growth. International Review of Economics \& Finance 41, 23-39.

King, R.G., Levine, R., 1993a. Finance and Growth: Schumpeter Might be Right. The Quarterly Journal of Economics 108, 717-737.

King, R.G., Levine, R., 1993b. Finance, entrepreneurship and growth. Journal of Monetary Economics 32, 513-542. 
Klein, M.W., Olivei, G.P., 2008. Capital account liberalization, financial depth, and economic growth. Journal of International Money and Finance 27, 861-875.

Kose, M.A., Prasad, E., Rogoff, K., Wei, S.-J., 2009. Financial Globalization: A Reappraisal. IMF Staff Papers 56, 8-62.

Larrain, B., 2006. Do banks affect the level and composition of industrial volatility? Journal of Finance 61, 1897-1925.

Law, S.H., Singh, N., 2014. Does too much finance harm economic growth? Journal of Banking \& Finance 41, 36-44.

Levine, R., 1997. Financial development and economic growth: Views and agenda. Journal of Economic Literature 35, 688-726.

Levine, R., Loayza, N., Beck, T., 2000. Financial intermediation and growth: Causality and causes. Journal of Monetary Economics 46, 31-77.

Lin, J.Y., Sun, X., Wu, H.X., 2015. Banking structure and industrial growth: Evidence from China. Journal of Banking \& Finance 58, 131-143.

Liu, G., Mirzaei, A., Vandoros, S., 2014. The impact of bank competition and concentration on industrial growth. Economics Letters 124, 60-63.

Love, I., 2003. Financial development and financing constraints: International evidence from the structural investment model. Review of Financial Studies 16, 765-791.

Lucchetti, R., Papi, L., Zazzaro, A., 2001. Banks' inefficiency and economic growth: A micro-macro approach. Scottish Journal of Political Economy 48, 400-424.

Manganelli, S., Popov, A., 2015. Financial development, sectoral reallocation, and volatility: International evidence. Journal of International Economics 96, 323-337.

Mendoza, E.G., Terrones, M.E., 2008. An Anatomy of Credit Booms: Evidence from Macro Aggregates and Micro Data, NBER Working Paper 14049 (May). National Bureau of Economic Research, Cambridge, MA. 
Mirzaei, A., Moore, T., 2016. Banking performance and industry growth in an oil-rich economy: Evidence from Qatar. The Quarterly Review of Economics and Finance 60, $58-69$.

Nyasha, S., Odhiambo, N.M., 2014. Bank-based financial development and economic growth: A review of international literature. Journal of Financial Economic Policy 6, $112-132$.

O’Connor, M., Rafferty, M., 2012. Corporate governance and innovation. Journal of Financial and Quantitative Analysis 47, 397-413.

Pang, J., Wu, H., 2009. Financial markets, financial dependence, and the allocation of capital. Journal of Banking \& Finance 33, 810-818.

Pedroni, P., 1999. Critical values for cointegration tests in heterogeneous panels with multiple regressors. Oxford Bulletin of Economics and Statistics 61, 653-670.

Pedroni, P., 2004. Panel cointegration: Asymptotic and finite sample properties of pooled time series tests with an application to the ppp hypothesis. Econometric Theory 20, $597-625$.

Rajan, R.G., Zingales, L., 1998. Financial dependence and growth. American Economic Review 88, 559-586.

Ranis, G., John, C.H.F., 1961. A Theory of Economic Development. The American Economic Review 51, 533-565.

Rioja, F., Valev, N., 2004. Finance and the Sources of Growth at Various Stages of Economic Development. Economic Inquiry 42, 127-140.

Sahay, R., Cihak, M., N'Diaye, P.M., Barajas, A., Ayala Pena, D.B., Bi, R., Gao, Y., Kyobe, A.J., Nguyen, L., Saborowski, C., Svirydzenka, K., Yousefi, R., 2015. Rethinking Financial Deepening : Stability and Growth in Emerging Markets, IMF Discussion Note, SDN/15/08. 
Samargandi, N., Fidrmuc, J., Ghosh, S., 2015. Is the Relationship Between Financial Development and Economic Growth Monotonic? Evidence from a Sample of MiddleIncome Countries. World Development 68, 66-81.

Wagner, W., 2007. The liquidity of bank assets and banking stability. Journal of Banking \& Finance 31, 121-139.

Zeira, J., 1999. Informational overshooting, booms, and crashes. Journal of Monetary Economics 43, 237-257. 
Figure 1: Hypothetical Relations between Economic and Financial Development

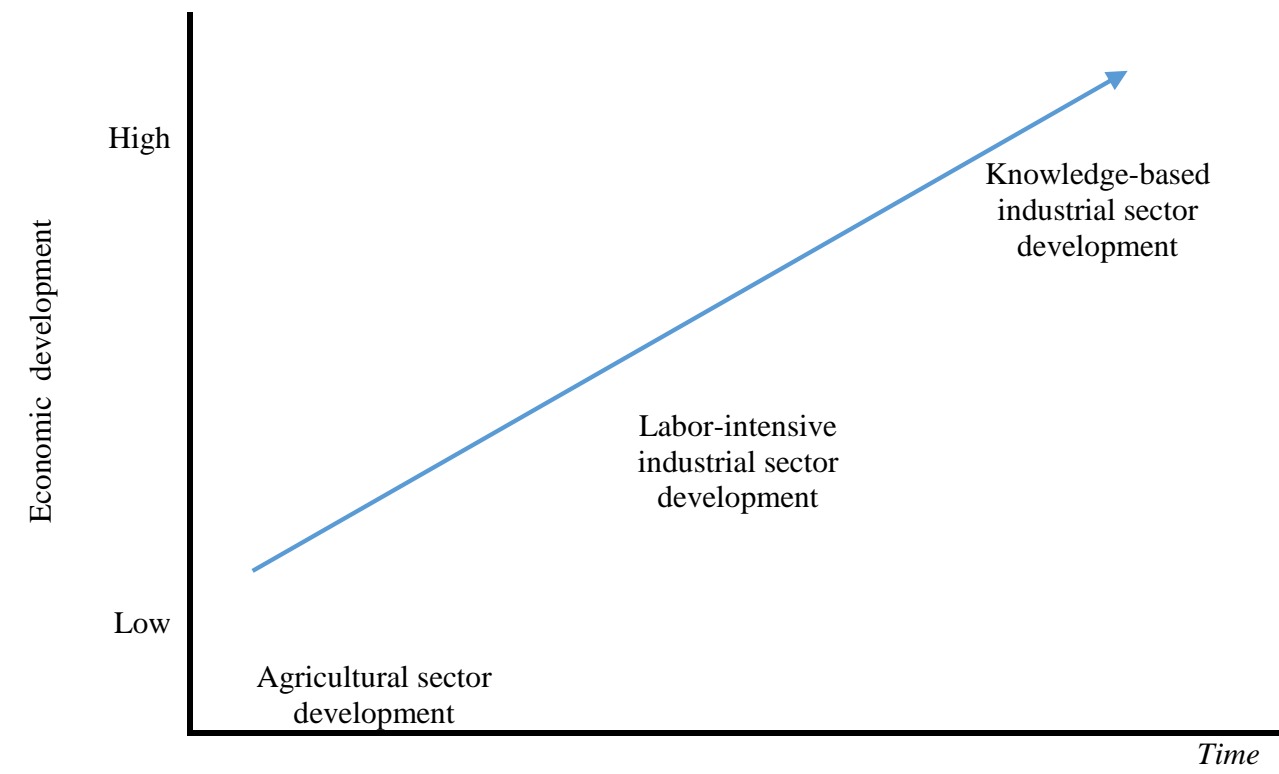

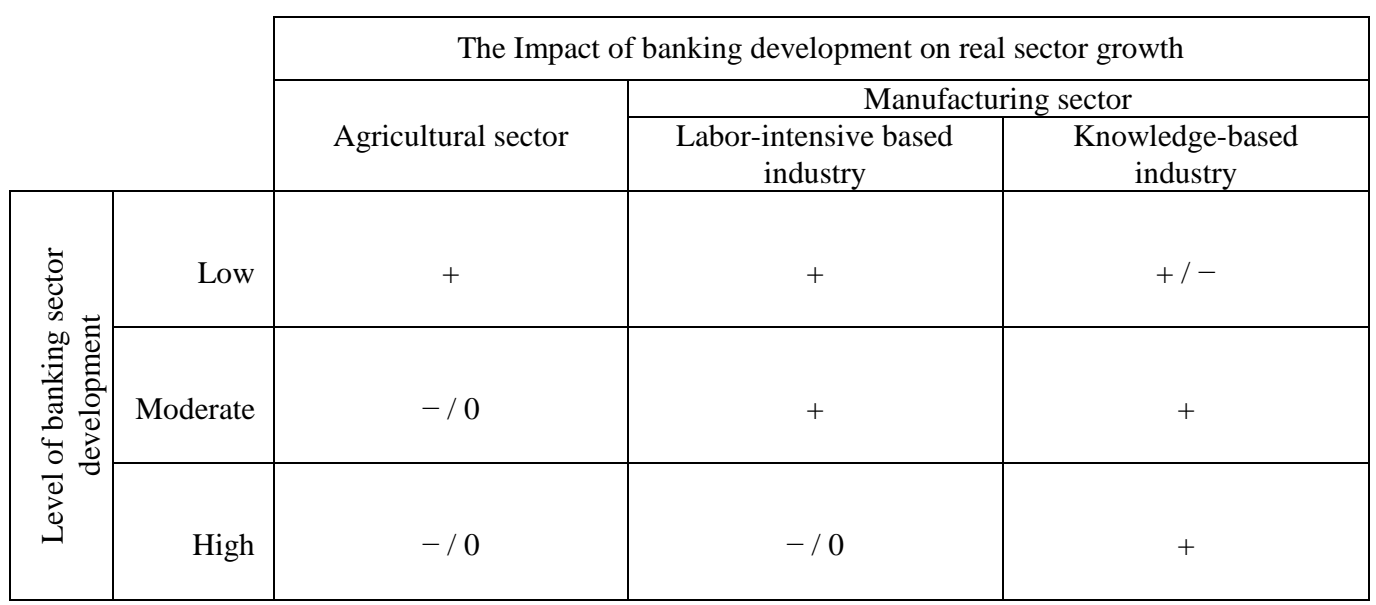

Note that,+- and 0 refer to a positive effect, a negative effect, and neutral or no effect, respectively. 
Table 1: Summary statistics of key variables

This table displays summary statistics for key variables in the full sample during 1960-2016. AGRDEV is the value added by the agricultural sector as a percentage of GDP. INDDEV is the value added by the industry sector as a percentage of GDP. LNAGRDEV is the natural logarithm of the value added by the agricultural sector as a percentage of GDP. LNINDDEV is the natural logarithm of the value added by the industry sector as a percentage of GDP. LNBANK1 is the natural logarithm of BANK1, which is the share of domestic credit to the private sector by banks as a percentage of GDP. LNBANK2 is the natural logarithm of BANK2, which is the share of domestic credit provided by the financial sector as a percentage of GDP. LNBANK3 is the natural logarithm of BANK3, which is the number of commercial bank branches (per 100,000 adults). GDP is real GDP per capita. GDP growth $(\triangle \mathrm{GDP})$ is measured as the first difference in the natural logarithm of real GDP per capita. Net foreign asset (FAGDP) is computed as the net foreign asset as a percentage of GDP. Government spending (GOVGDP) is measured as the final consumption expenditures of general government as a percentage of GDP. Inflation (INF) is measured as the GDP deflator in annual percentage. Interest rate (INT) is measured as the real interest rate in percentage. Investment (INV) is measured as gross fixed capital formation as a percentage to GDP. Trade openness (TRADE) is measured as the total trade as a percentage to GDP.

\begin{tabular}{lrrrrrr}
\hline Variable & Mean & Median & Std. Dev. & Min & Max & N \\
\hline AGRDEV & 17.91 & 13.65 & 14.52 & 1.09 & 49.42 & 6,705 \\
INDDEV & 28.36 & 27.59 & 10.89 & 11.32 & 52.68 & 6,674 \\
BANK1 & 36.11 & 26.15 & 29.80 & 4.62 & 112.37 & 7,786 \\
BANK2 & 34.04 & 25.22 & 27.72 & 4.17 & 104.24 & 7,823 \\
BANK3 & 17.33 & 12.70 & 15.12 & 1.19 & 55.65 & 2,128 \\
LNAGRDEV & 2.42 & 2.61 & 1.10 & 0.08 & 3.90 & 6,705 \\
LNINDDEV & 3.27 & 3.32 & 0.41 & 2.43 & 3.96 & 6,674 \\
LNBANK1 & 3.23 & 3.26 & 0.88 & 1.53 & 4.72 & 7,786 \\
LNBANK2 & 3.17 & 3.23 & 0.89 & 1.43 & 4.65 & 7,823 \\
LNBANK3 & 2.37 & 2.54 & 1.10 & 0.18 & 4.02 & 2,128 \\
GDP & $7,945.98$ & $3,108.62$ & $10,467.47$ & 361.59 & $44,050.04$ & 8,288 \\
$\Delta$ GDP & 0.02 & 0.02 & 0.06 & -1.05 & 0.88 & 8,081 \\
FAGDP & 11.41 & 7.32 & 18.13 & -17.05 & 59.94 & 7,757 \\
GOVGDP & 15.64 & 15.09 & 5.54 & 7.23 & 27.48 & 8,005 \\
INF & 9.31 & 5.47 & 11.44 & -1.80 & 45.09 & 8,842 \\
INT & 6.04 & 5.62 & 7.30 & -8.86 & 21.58 & 4,939 \\
INVGDP & 21.94 & 21.62 & 6.77 & 10.24 & 36.23 & 7,406 \\
TRADE & 75.34 & 68.84 & 37.85 & 22.21 & 159.03 & 8,344 \\
\hline
\end{tabular}


Table 2: The effect of banking sector development on industrial sector development.

This table presents the results of panel OLS regressions of the effect of banking sector development on industrial sector development during the period 1966-2016. The dependent variable is LNINDDEV, which is the natural logarithm of the value added by the industry sector as a percentage of GDP. LNBANK1 is the natural logarithm of BANK1, which is the share of domestic credit to the private sector by banks as a percentage of GDP. LNBANK2 is the natural logarithm of BANK2, which is the share of domestic credit provided by the financial sector as a percentage of GDP. LNBANK3 is the natural logarithm of BANK3, which is the number of commercial bank branches (per 100,000 adults). Please see other variable definitions in Table 1. Country- and year-fixed effects are included in all models. Standard errors, which are reported in parentheses, are robust to heteroskedasticity and serial correlation and are clustered at the country level. Symbols ***,**, and * denote statistical significance at the $1 \%, 5 \%$ and $10 \%$ levels, respectively.

\begin{tabular}{|c|c|c|c|c|c|c|}
\hline \multirow[t]{2}{*}{ Variable } & (1) & (2) & (3) & (4) & (5) & (6) \\
\hline & OLS & OLS & OLS & DOLS & DOLS & DOLS \\
\hline \multirow[t]{2}{*}{ LNINDDEV $_{\mathrm{t}-1}$} & & & & $0.809 * * *$ & $0.809 * * *$ & $0.525 * * *$ \\
\hline & & & & $(0.011)$ & $(0.011)$ & $(0.029)$ \\
\hline \multirow[t]{2}{*}{ FAGDP $_{t-1}$} & 0.000 & 0.000 & $0.002 * * *$ & 0.000 & 0.000 & $0.001 * * *$ \\
\hline & $(0.001)$ & $(0.001)$ & $(0.001)$ & $(0.000)$ & $(0.000)$ & $(0.000)$ \\
\hline \multirow[t]{2}{*}{$\mathrm{GDP}_{\mathrm{t}-1}$} & $0.000 * * *$ & $0.000 * * *$ & 0.000 & $0.000 * * *$ & $0.000 * * *$ & $0.000 * *$ \\
\hline & $(0.000)$ & $(0.000)$ & $(0.000)$ & $(0.000)$ & $(0.000)$ & $(0.000)$ \\
\hline \multirow[t]{2}{*}{$\Delta \mathrm{GDP}_{\mathrm{t}-1}$} & 0.114 & 0.125 & 0.121 & 0.028 & 0.034 & -0.010 \\
\hline & $(0.084)$ & $(0.085)$ & $(0.091)$ & $(0.040)$ & $(0.040)$ & $(0.072)$ \\
\hline \multirow{2}{*}{ GOVGDP $_{\mathrm{t}-1}$} & $-0.006 * * *$ & $-0.006 * * *$ & $-0.009 * * *$ & $-0.002 * *$ & $-0.002 * *$ & $-0.005 * * *$ \\
\hline & $(0.002)$ & $(0.002)$ & $(0.002)$ & $(0.001)$ & $(0.001)$ & $(0.002)$ \\
\hline \multirow[t]{2}{*}{$\mathrm{INT}_{\mathrm{t}-1}$} & $-0.001 * *$ & $-0.001 * *$ & -0.001 & $-0.001 *$ & $-0.001 * *$ & 0.000 \\
\hline & $(0.001)$ & $(0.001)$ & $(0.001)$ & $(0.000)$ & $(0.000)$ & $(0.001)$ \\
\hline \multirow[t]{2}{*}{ INVGDP $_{\mathrm{t}-1}$} & $0.006^{* * *}$ & $0.006^{* * *}$ & $0.004 * * *$ & $0.001 * * *$ & $0.001 * * *$ & $0.002 * *$ \\
\hline & $(0.001)$ & $(0.001)$ & $(0.001)$ & $(0.000)$ & $(0.000)$ & $(0.001)$ \\
\hline \multirow[t]{2}{*}{ TRADE $_{t-1}$} & $0.001 * * *$ & $0.001 * * *$ & $0.001 * * *$ & 0.000 & 0.000 & $0.001 * *$ \\
\hline & $(0.000)$ & $(0.000)$ & $(0.000)$ & $(0.000)$ & $(0.000)$ & $(0.000)$ \\
\hline \multirow[t]{2}{*}{ LNBANK $1_{\mathrm{t}-1}$} & -0.004 & & & -0.005 & & \\
\hline & $(0.016)$ & & & $(0.005)$ & & \\
\hline \multirow[t]{2}{*}{ LNBANK $2_{\mathrm{t}-1}$} & & 0.003 & & & -0.003 & \\
\hline & & $(0.016)$ & & & $(0.005)$ & \\
\hline \multirow[t]{2}{*}{$\mathrm{LNBANK}_{\mathrm{t}-1}$} & & & 0.032 & & & 0.011 \\
\hline & & & $(0.024)$ & & & $(0.015)$ \\
\hline Country-fixed effects & Yes & Yes & Yes & Yes & Yes & Yes \\
\hline Year-fixed effects & Yes & Yes & Yes & Yes & Yes & Yes \\
\hline Adjusted $R^{2}$ & 0.859 & 0.859 & 0.951 & 0.951 & 0.951 & 0.966 \\
\hline F-statistic & $97.713 * * *$ & $97.241 * * *$ & $156.562 * * *$ & $304.374 * * *$ & $303.322 * * *$ & $227.476^{* * *}$ \\
\hline Countries included & 156 & 156 & 143 & 156 & 156 & 143 \\
\hline Observations & 3,379 & 3,369 & 1,316 & 3,340 & 3,330 & 1,311 \\
\hline
\end{tabular}


Table 3: The effect of banking sector development on agricultural sector development.

This table presents the results of panel OLS regressions of the effect of banking sector development on agricultural sector development during the period 1966-2016. The dependent variable is LNAGRDEV, which is the natural logarithm of the value added by the agricultural sector as a percentage of GDP. LNBANK1 is the natural logarithm of BANK1. LNBANK2 is the natural logarithm of BANK2. LNBANK3 is the natural logarithm of BANK3. Please see other variable definitions in Table 1. Country- and year-fixed effects are included in all models. Standard errors, which are reported in parentheses, are robust to heteroskedasticity and serial correlation and are clustered at the country level. Symbols ***, $* *$, and $*$ denote statistical significance at the $1 \%, 5 \%$ and $10 \%$ levels, respectively.

\begin{tabular}{|c|c|c|c|c|c|c|}
\hline Variable & $\begin{array}{r}(1) \\
\text { OLS } \\
\end{array}$ & $\begin{array}{r}(2) \\
\text { OLS } \\
\end{array}$ & $\begin{array}{r}(3) \\
\text { OLS } \\
\end{array}$ & $\begin{array}{r}(4) \\
\text { DOLS } \\
\end{array}$ & $\begin{array}{r}(5) \\
\text { DOLS } \\
\end{array}$ & $\begin{array}{r}(6) \\
\text { DOLS } \\
\end{array}$ \\
\hline LNAGRDEV $_{\mathrm{t}-1}$ & & & & $\begin{array}{r}0.842^{* * * *} \\
(0.010)\end{array}$ & $\begin{array}{r}0.842 * * * \\
(0.010)\end{array}$ & $\begin{array}{r}0.653 * * * \\
(0.025)\end{array}$ \\
\hline FAGDP $_{t-1}$ & $\begin{array}{r}-0.003 * * * \\
(0.001)\end{array}$ & $\begin{array}{r}-0.002 * * * \\
(0.001)\end{array}$ & $\begin{array}{r}-0.001 \\
(0.001)\end{array}$ & $\begin{array}{r}-0.001 * * * \\
(0.000)\end{array}$ & $\begin{array}{r}-0.001 * * * * \\
(0.000)\end{array}$ & $\begin{array}{r}-0.001 \\
(0.000)\end{array}$ \\
\hline $\mathrm{GDP}_{\mathrm{t}-1}$ & $\begin{array}{r}0.000^{* * * *} \\
(0.000)\end{array}$ & $\begin{array}{r}0.000 * * * \\
(0.000)\end{array}$ & $\begin{array}{r}0.000^{* * * *} \\
(0.000)\end{array}$ & $\begin{array}{r}0.000^{* * * *} \\
(0.000)\end{array}$ & $\begin{array}{r}0.000 * * * \\
(0.000)\end{array}$ & $\begin{array}{r}0.000 * * * \\
(0.000)\end{array}$ \\
\hline$\Delta \mathrm{GDP}_{\mathrm{t}-1}$ & $\begin{array}{r}-0.071 \\
(0.116)\end{array}$ & $\begin{array}{r}-0.051 \\
(0.116)\end{array}$ & $\begin{array}{r}0.012 \\
(0.133)\end{array}$ & $\begin{array}{r}-0.273 * * * \\
(0.047)\end{array}$ & $\begin{array}{r}-0.271^{* * * *} \\
(0.047)\end{array}$ & $\begin{array}{r}-0.064 \\
(0.092)\end{array}$ \\
\hline $\operatorname{GOVGDP}_{\mathrm{t}-1}$ & $\begin{array}{l}-0.005^{*} \\
(0.003)\end{array}$ & $\begin{array}{l}-0.006^{*} \\
(0.003)\end{array}$ & $\begin{array}{r}0.000 \\
(0.004)\end{array}$ & $\begin{array}{r}0.000 \\
(0.001)\end{array}$ & $\begin{array}{r}0.000 \\
(0.001)\end{array}$ & $\begin{array}{r}0.002 \\
(0.002)\end{array}$ \\
\hline $\mathrm{INT}_{\mathrm{t}-1}$ & $\begin{array}{r}0.001 \\
(0.001)\end{array}$ & $\begin{array}{r}0.001 \\
(0.001)\end{array}$ & $\begin{array}{r}0.002 * * \\
(0.001)\end{array}$ & $\begin{array}{r}0.000 \\
(0.000)\end{array}$ & $\begin{array}{r}0.000 \\
(0.000)\end{array}$ & $\begin{array}{r}0.001 \\
(0.001)\end{array}$ \\
\hline INVGDP $_{t-1}$ & $\begin{array}{l}-0.002 \\
(0.002)\end{array}$ & $\begin{array}{l}-0.002 \\
(0.002)\end{array}$ & $\begin{array}{r}-0.004 * * \\
(0.002)\end{array}$ & $\begin{array}{r}-0.001 * * * \\
(0.000)\end{array}$ & $\begin{array}{r}-0.001 * * \\
(0.000)\end{array}$ & $\begin{array}{r}-0.002 * * * \\
(0.001)\end{array}$ \\
\hline TRADE $_{t-1}$ & $\begin{array}{r}0.000 \\
(0.001)\end{array}$ & $\begin{array}{r}0.000 \\
(0.001)\end{array}$ & $\begin{array}{r}0.001^{* *} \\
(0.001)\end{array}$ & $\begin{array}{r}0.000 \\
(0.000)\end{array}$ & $\begin{array}{r}0.000 \\
(0.000)\end{array}$ & $\begin{array}{r}0.000 \\
(0.000)\end{array}$ \\
\hline LNBANK $1_{t-1}$ & $\begin{array}{r}-0.102 * * * \\
(0.023)\end{array}$ & & & $\begin{array}{l}-0.010^{*} \\
(0.006)\end{array}$ & & \\
\hline LNBANK $2_{t-1}$ & & $\begin{array}{r}-0.100 * * * \\
(0.023)\end{array}$ & & & $\begin{array}{l}-0.010^{*} \\
(0.006)\end{array}$ & \\
\hline LNBANK $_{\mathrm{t}-1}$ & & & $\begin{array}{l}-0.056 \\
(0.035)\end{array}$ & & & $\begin{array}{r}-0.011 \\
(0.016)\end{array}$ \\
\hline $\begin{array}{l}\text { Country-fixed } \\
\text { effects }\end{array}$ & Yes & Yes & Yes & Yes & Yes & Yes \\
\hline Year-fixed effects & yes & yes & yes & yes & yes & yes \\
\hline Adjusted $R^{2}$ & $\begin{array}{r}0.966 \\
455.461 * * \\
*\end{array}$ & $\begin{array}{r}0.966 \\
456.284 * * \\
*\end{array}$ & $\begin{array}{r}0.986 \\
568.747 * * \\
*\end{array}$ & $\begin{array}{r}0.990 \\
1,597.799 * *\end{array}$ & $\begin{array}{r}0.990 \\
1,599.024 * * \\
*\end{array}$ & $\begin{array}{r}0.992 \\
1,010.837 * * \\
*\end{array}$ \\
\hline $\begin{array}{l}\text { F-statistic } \\
\text { Countries included }\end{array}$ & $\begin{array}{r}* \\
156\end{array}$ & $\begin{array}{r}* \\
156\end{array}$ & $\begin{array}{r}* \\
143\end{array}$ & $\begin{array}{r}* \\
156\end{array}$ & $\begin{array}{r}* \\
156\end{array}$ & $\begin{array}{r}* \\
143\end{array}$ \\
\hline Observations & 3,388 & 3,378 & 1,317 & 3,349 & 3,339 & 1,312 \\
\hline
\end{tabular}


Table 4: The effect of banking sector development on industrial sector development:

Subsamples.

This table presents the results of panel dynamic OLS regressions of the effect of banking sector development on industrial sector development during the period 1966-2016. The dependent variable is LNINDDEV, which is the natural logarithm of the value added by the industry sector as a percentage of GDP. LNBANK1 is the natural logarithm of BANK1. LNBANK2 is the natural logarithm of BANK2. LNBANK3 is the natural logarithm of BANK3. HBSD1 takes a value of one for observations when the value of LNBANK1 is larger than the cross-sectional median value of LNBANK1, and zero otherwise. HBSD2 takes a value of one for observations when the value of LNBANK2 is larger than the crosssectional median value of LNBANK2. HBSD3 takes a value of one for observations when the value of LNBANK3 is larger than the cross-sectional median value of LNBANK3. Please see other variable definitions in Table 1. Country- and year-fixed effects are included in all models. Standard errors, which are reported in parentheses, are robust to heteroskedasticity and serial correlation and are clustered at the country level. Symbols ***, **, and * denote statistical significance at the $1 \%, 5 \%$ and $10 \%$ levels, respectively.

\begin{tabular}{|c|c|c|c|c|c|c|}
\hline \multirow[t]{2}{*}{ Variable } & (1) & (2) & (3) & (4) & (5) & (6) \\
\hline & $\mathrm{HBSD} 1=0$ & $\mathrm{HBSD} 1=1$ & $\mathrm{HBSD} 2=0$ & $\mathrm{HBSD} 2=1$ & $\mathrm{HBSD} 3=0$ & $\mathrm{HBSD} 3=1$ \\
\hline \multirow{2}{*}{ LNINDDEV $_{\mathrm{t}-1}$} & $0.766 * * *$ & $0.863 * * *$ & $0.770 * * *$ & $0.860 * * *$ & $0.449 * * *$ & $0.547 * * *$ \\
\hline & $(0.018)$ & $(0.015)$ & $(0.018)$ & $(0.015)$ & $(0.042)$ & $(0.048)$ \\
\hline \multirow[t]{2}{*}{ FAGDP $_{t-1}$} & 0.000 & 0.000 & 0.000 & 0.000 & $0.002 * * *$ & 0.000 \\
\hline & $(0.000)$ & $(0.000)$ & $(0.000)$ & $(0.000)$ & (0.001) & $(0.000)$ \\
\hline \multirow[t]{2}{*}{$\mathrm{GDP}_{\mathrm{t}-1}$} & $0.000 * *$ & $0.000 * *$ & $0.000 * *$ & $0.000^{* *}$ & $0.000 *$ & $0.000 * *$ \\
\hline & $(0.000)$ & $(0.000)$ & $(0.000)$ & $(0.000)$ & $(0.000)$ & $(0.000)$ \\
\hline \multirow[t]{2}{*}{$\Delta \mathrm{GDP}_{\mathrm{t}-1}$} & 0.019 & 0.049 & 0.048 & 0.028 & -0.015 & -0.024 \\
\hline & (0.068) & $(0.047)$ & $(0.069)$ & $(0.048)$ & (0.109) & $(0.099)$ \\
\hline \multirow[t]{2}{*}{ GOVGDP $_{\mathrm{t}-1}$} & -0.001 & $-0.002 * *$ & -0.001 & $-0.003 * * *$ & $-0.004 *$ & $-0.007 * * *$ \\
\hline & $(0.001)$ & $(0.001)$ & $(0.001)$ & $(0.001)$ & $(0.002)$ & $(0.003)$ \\
\hline \multirow[t]{2}{*}{$\mathrm{INT}_{\mathrm{t}-1}$} & -0.001 & -0.001 & -0.001 & 0.000 & -0.001 & 0.000 \\
\hline & $(0.000)$ & $(0.000)$ & $(0.000)$ & $(0.000)$ & $(0.001)$ & $(0.001)$ \\
\hline \multirow[t]{2}{*}{$\mathrm{INVGDP}_{\mathrm{t}-1}$} & $0.002 * * *$ & 0.000 & $0.002 * * *$ & 0.000 & 0.002 & $0.002^{*}$ \\
\hline & $(0.001)$ & $(0.000)$ & $(0.001)$ & $(0.000)$ & $(0.001)$ & $(0.001)$ \\
\hline \multirow[t]{2}{*}{ TRADE $_{t-1}$} & 0.000 & 0.000 & 0.000 & 0.000 & 0.000 & $0.001 * * *$ \\
\hline & $(0.000)$ & $(0.000)$ & $(0.000)$ & $(0.000)$ & $(0.000)$ & $(0.000)$ \\
\hline \multirow[t]{2}{*}{ LNBANK $1_{t-1}$} & 0.013 & -0.008 & & & & \\
\hline & (0.008) & (0.008) & & & & \\
\hline \multirow[t]{2}{*}{ LNBANK $2_{t-1}$} & & & $0.014 *$ & -0.005 & & \\
\hline & & & $(0.008)$ & (0.009) & & \\
\hline \multirow[t]{2}{*}{$\mathrm{LNBANK}_{\mathrm{t}-1}$} & & & & & 0.010 & 0.007 \\
\hline & & & & & $(0.021)$ & $(0.025)$ \\
\hline Country-fixed effects & Yes & Yes & Yes & Yes & Yes & Yes \\
\hline Year-fixed effects & Yes & Yes & Yes & Yes & Yes & Yes \\
\hline Adjusted $R^{2}$ & 0.936 & 0.971 & 0.935 & 0.971 & 0.967 & 0.971 \\
\hline F-statistic & $142.484 * * *$ & $364.827 * * *$ & $144.462 * * *$ & $357.910 * * *$ & $179.191 * * *$ & $216.525 * * *$ \\
\hline Countries included & 106 & 106 & 105 & 109 & 81 & 75 \\
\hline Observations & 1,538 & 1,776 & 1,545 & 1,761 & 613 & 609 \\
\hline
\end{tabular}


Table 5: The effect of banking sector development on agricultural sector development: Subsamples.

This table presents the results of panel dynamic OLS regressions of the effect of banking sector development on agricultural sector development during the period 1966-2016. The dependent variable is LNAGRDEV, which is the natural logarithm of the value added by the agricultural sector as a percentage of GDP. LNBANK1 is the natural logarithm of BANK1. LNBANK2 is the natural logarithm of BANK2. LNBANK3 is the natural logarithm of BANK3. HBSD1 takes a value of one for observations when the value of LNBANK1 is larger than the cross-sectional median value of LNBANK1, and zero otherwise. HBSD2 takes a value of one for observations when the value of LNBANK2 is larger than the crosssectional median value of LNBANK2. HBSD3 takes a value of one for observations when the value of LNBANK3 is larger than the cross-sectional median value of LNBANK3. Please see other variable definitions in Table 1. Country- and year-fixed effects are included in all models. Standard errors, which are reported in parentheses, are robust to heteroskedasticity and serial correlation and are clustered at the country level. Symbols ***, **, and * denote statistical significance at the $1 \%, 5 \%$ and $10 \%$ levels, respectively.

\begin{tabular}{|c|c|c|c|c|c|c|}
\hline \multirow[t]{2}{*}{ Variable } & (1) & (2) & (3) & (4) & (5) & (6) \\
\hline & $\mathrm{HBSD} 1=0$ & $\mathrm{HBSD} 1=1$ & $\mathrm{HBSD} 2=0$ & $\mathrm{HBSD} 2=1$ & $\mathrm{HBSD} 3=0$ & HBSD $3=1$ \\
\hline \multirow{2}{*}{ LNAGRDEV $_{\mathrm{t}-1}$} & $0.794 * * *$ & $0.856 * * *$ & $0.788 * * *$ & $0.859 * * *$ & $0.615^{* * *}$ & $0.637 * * *$ \\
\hline & $(0.016)$ & $(0.014)$ & $(0.016)$ & $(0.014)$ & $(0.040)$ & $(0.038)$ \\
\hline \multirow[t]{2}{*}{$\mathrm{FAGDP}_{\mathrm{t}-1}$} & $-0.001 * * *$ & $-0.001 * *$ & $-0.001 * * *$ & $-0.001 * *$ & 0.000 & -0.001 \\
\hline & $(0.000)$ & $(0.000)$ & $(0.000)$ & $(0.000)$ & $(0.001)$ & $(0.001)$ \\
\hline \multirow[t]{2}{*}{$\mathrm{GDP}_{\mathrm{t}-1}$} & $0.000 * * *$ & $0.000 * * *$ & $0.000 * * *$ & $0.000 * * *$ & 0.000 & $0.000 * *$ \\
\hline & $(0.000)$ & $(0.000)$ & $(0.000)$ & $(0.000)$ & $(0.000)$ & $(0.000)$ \\
\hline \multirow[t]{2}{*}{$\Delta \mathrm{GDP}_{\mathrm{t}-1}$} & $-0.208 * * *$ & $-0.392 * * *$ & $-0.242 * * *$ & $-0.306^{* * *}$ & -0.021 & -0.167 \\
\hline & $(0.065)$ & $(0.077)$ & $(0.066)$ & $(0.075)$ & (0.133) & $(0.156)$ \\
\hline \multirow{2}{*}{ GOVGDP $_{\mathrm{t}-1}$} & 0.000 & -0.001 & 0.000 & -0.001 & 0.000 & 0.002 \\
\hline & $(0.001)$ & $(0.001)$ & $(0.001)$ & $(0.001)$ & $(0.002)$ & $(0.004)$ \\
\hline \multirow[t]{2}{*}{$\mathrm{INT}_{\mathrm{t}-1}$} & 0.001 & 0.000 & 0.001 & 0.000 & $0.002 *$ & -0.001 \\
\hline & $(0.000)$ & $(0.001)$ & $(0.000)$ & $(0.001)$ & $(0.001)$ & $(0.001)$ \\
\hline \multirow[t]{2}{*}{ INVGDP $_{\mathrm{t}-1}$} & $-0.001 *$ & -0.001 & -0.001 & $-0.001^{*}$ & $-0.003^{* *}$ & -0.002 \\
\hline & $(0.001)$ & $(0.001)$ & $(0.001)$ & $(0.001)$ & $(0.001)$ & $(0.001)$ \\
\hline \multirow[t]{2}{*}{ TRADE $_{t-1}$} & 0.000 & 0.000 & 0.000 & 0.000 & 0.000 & 0.000 \\
\hline & $(0.000)$ & $(0.000)$ & $(0.000)$ & $(0.000)$ & $(0.000)$ & $(0.001)$ \\
\hline \multirow[t]{2}{*}{ LNBANK $1_{t-1}$} & -0.011 & $-0.025 * *$ & & & & \\
\hline & (0.009) & $(0.012)$ & & & & \\
\hline \multirow[t]{2}{*}{ LNBANK $2_{\mathrm{t}-1}$} & & & -0.013 & $-0.027 * *$ & & \\
\hline & & & (0.009) & $(0.012)$ & & \\
\hline \multirow[t]{2}{*}{$\mathrm{LNBANK}_{\mathrm{t}-1}$} & & & & & -0.001 & -0.017 \\
\hline & & & & & $(0.023)$ & $(0.034)$ \\
\hline Country-fixed effects & Yes & Yes & Yes & Yes & Yes & Yes \\
\hline Year-fixed effects & Yes & Yes & Yes & Yes & Yes & Yes \\
\hline Adjusted $R^{2}$ & 0.984 & 0.989 & 0.984 & 0.990 & 0.989 & 0.989 \\
\hline F-statistic & $611.128 * * *$ & $1,006.616^{* * *}$ & $597.191 * * *$ & $1,063.073^{* * *}$ & $561.499 * * *$ & $601.421 * * *$ \\
\hline Countries included & 106 & 106 & 106 & 109 & 81 & 75 \\
\hline Observations & 1,539 & 1,784 & 1,548 & 1,767 & 613 & 609 \\
\hline
\end{tabular}


Table 6: The effect of banking sector development on industrial sector growth

This table presents the results of panel OLS regressions of the effect of banking sector development on industrial sector growth during the period 1966-2016. The dependent variable is $\triangle I N D S I Z E$, which is the first difference in the natural logarithm of the real value added by the industry sector in USD. LNBANK1 is the natural logarithm of BANK1. LNBANK2 is the natural logarithm of BANK2. LNBANK3 is the natural logarithm of BANK3. Please see other variable definitions in Table 1. Country- and year-fixed effects are included in all models. Standard errors, which are reported in parentheses, are robust to heteroskedasticity and serial correlation and are clustered at the country level. Symbols ***, $* *$, and $*$ denote statistical significance at the $1 \%, 5 \%$ and $10 \%$ levels, respectively.

\begin{tabular}{|c|c|c|c|c|c|c|}
\hline Variable & $\begin{array}{r}(1) \\
\text { OLS }\end{array}$ & $\begin{array}{r}(2) \\
\text { OLS }\end{array}$ & $\begin{array}{r}\text { (3) } \\
\text { OLS }\end{array}$ & $\begin{array}{r}(4) \\
\text { DOLS }\end{array}$ & $\begin{array}{r}(5) \\
\text { DOLS }\end{array}$ & $\begin{array}{r}(6) \\
\text { DOLS }\end{array}$ \\
\hline$\Delta$ INDSIZE $_{\mathrm{t}-1}$ & & & & $\begin{array}{r}0.087 * * * \\
(0.020)\end{array}$ & $\begin{array}{r}0.085 * * * \\
(0.020)\end{array}$ & $\begin{array}{r}0.077 * * \\
(0.037)\end{array}$ \\
\hline FAGDP $_{t-1}$ & $\begin{array}{r}0.001 * * * \\
(0.000)\end{array}$ & $\begin{array}{r}0.001 * * * \\
(0.000)\end{array}$ & $\begin{array}{r}0.001 * * * \\
(0.000)\end{array}$ & $\begin{array}{r}0.001 * * * \\
(0.000)\end{array}$ & $\begin{array}{r}0.001 * * * \\
(0.000)\end{array}$ & $\begin{array}{r}0.001 * * * * \\
(0.000)\end{array}$ \\
\hline $\mathrm{GDP}_{\mathrm{t}-1}$ & $\begin{array}{r}0.000 * * \\
(0.000)\end{array}$ & $\begin{array}{r}0.000 * * \\
(0.000)\end{array}$ & $\begin{array}{r}0.000 * * * \\
(0.000)\end{array}$ & $\begin{array}{r}0.000 * * * \\
(0.000)\end{array}$ & $\begin{array}{r}0.000 * * * \\
(0.000)\end{array}$ & $\begin{array}{r}0.000 * * * * \\
(0.000)\end{array}$ \\
\hline$\Delta \mathrm{GDP}_{\mathrm{t}-1}$ & $\begin{array}{r}0.346 * * * \\
(0.037)\end{array}$ & $\begin{array}{r}0.346 * * * \\
(0.037)\end{array}$ & $\begin{array}{r}0.276 * * * \\
(0.077)\end{array}$ & $\begin{array}{r}0.241^{* * *} * \\
(0.045)\end{array}$ & $\begin{array}{r}0.243 * * * \\
(0.045)\end{array}$ & $\begin{array}{l}0.169 * \\
(0.093)\end{array}$ \\
\hline GOVGDP $_{\mathrm{t}-1}$ & $\begin{array}{r}-0.001 \\
(0.001)\end{array}$ & $\begin{array}{r}-0.001 \\
(0.001)\end{array}$ & $\begin{array}{r}0.000 \\
(0.002)\end{array}$ & $\begin{array}{r}-0.001 \\
(0.001)\end{array}$ & $\begin{array}{r}-0.001 \\
(0.001)\end{array}$ & $\begin{array}{r}0.000 \\
(0.002)\end{array}$ \\
\hline $\mathrm{INT}_{\mathrm{t}-1}$ & $\begin{array}{c}0.000 * \\
(0.000)\end{array}$ & $\begin{array}{l}0.000 * \\
(0.000)\end{array}$ & $\begin{array}{r}-0.001 \\
(0.001)\end{array}$ & $\begin{array}{l}0.000 * \\
(0.000)\end{array}$ & $\begin{array}{l}0.000 * \\
(0.000)\end{array}$ & $\begin{array}{l}-0.001 \\
(0.001)\end{array}$ \\
\hline $\mathrm{INVGDP}_{\mathrm{t}-1}$ & $\begin{array}{r}0.000 \\
(0.000)\end{array}$ & $\begin{array}{r}0.000 \\
(0.000)\end{array}$ & $\begin{array}{r}0.001 \\
(0.001)\end{array}$ & $\begin{array}{r}0.000 \\
(0.000)\end{array}$ & $\begin{array}{r}0.000 \\
(0.000)\end{array}$ & $\begin{array}{r}0.001 \\
(0.001)\end{array}$ \\
\hline TRADE $_{\mathrm{t}-1}$ & $\begin{array}{r}0.000 \\
(0.000)\end{array}$ & $\begin{array}{r}0.000 \\
(0.000)\end{array}$ & $\begin{array}{l}0.001 * \\
(0.000)\end{array}$ & $\begin{array}{r}0.000 \\
(0.000)\end{array}$ & $\begin{array}{r}0.000 \\
(0.000)\end{array}$ & $\begin{array}{l}0.000^{*} \\
(0.000)\end{array}$ \\
\hline $\mathrm{LNBANK} 1_{\mathrm{t}-1}$ & $\begin{array}{r}-0.010 * * \\
(0.004)\end{array}$ & & & $\begin{array}{r}-0.009 * * \\
(0.004)\end{array}$ & & \\
\hline LNBANK $2_{t-1}$ & & $\begin{array}{r}-0.008 * \\
(0.004)\end{array}$ & & & $\begin{array}{c}-0.007 * \\
(0.004)\end{array}$ & \\
\hline LNBANK $3_{t-1}$ & & & $\begin{array}{r}0.005 \\
(0.014)\end{array}$ & & & $\begin{array}{r}0.008 \\
(0.014)\end{array}$ \\
\hline Country-fixed effects & Yes & Yes & Yes & Yes & Yes & Yes \\
\hline Year-fixed effects & Yes & Yes & Yes & Yes & Yes & Yes \\
\hline Adjusted $R^{2}$ & 0.104 & 0.104 & 0.160 & 0.108 & 0.108 & 0.164 \\
\hline F-statistic & $2.853 * * *$ & $2.854 * * *$ & $2.557 * * *$ & $2.911 * * *$ & $2.909 * * *$ & $2.589 * * *$ \\
\hline Observations & 3,323 & 3,318 & 1,316 & 3,285 & 3,280 & 1,307 \\
\hline
\end{tabular}


Table 7: The effect of banking sector development on agricultural sector growth

This table presents the results of panel OLS regressions of the effect of banking sector development on agricultural sector growth during the period 1971-2014. The dependent variable is $\triangle$ AGRSIZE, which is the first difference in the natural logarithm of the real value added by the agricultural sector in USD. LNBANK1 is the natural logarithm of BANK1. LNBANK2 is the natural logarithm of BANK2. LNBANK3 is the natural logarithm of BANK3. Please see other variable definitions in Table 1. Country- and year-fixed effects are included in all models. Standard errors, which are reported in parentheses, are robust to heteroskedasticity and serial correlation and are clustered at the country level. Symbols ***, $* *$, and $*$ denote statistical significance at the $1 \%, 5 \%$ and $10 \%$ levels, respectively.

\begin{tabular}{|c|c|c|c|c|c|c|}
\hline Variable & $\begin{array}{r}(1) \\
\text { OLS }\end{array}$ & $\begin{array}{r}(2) \\
\text { OLS }\end{array}$ & $\begin{array}{r}(3) \\
\text { OLS }\end{array}$ & $\begin{array}{r}(4) \\
\text { DOLS }\end{array}$ & $\begin{array}{r}(5) \\
\text { DOLS }\end{array}$ & $\begin{array}{r}(6) \\
\text { DOLS }\end{array}$ \\
\hline$\Delta \mathrm{AGRSIZE}_{\mathrm{t}-1}$ & & & & $\begin{array}{r}-0.282 * * * \\
(0.019)\end{array}$ & $\begin{array}{r}-0.281 * * * \\
(0.019)\end{array}$ & $\begin{array}{r}-0.307 * * * \\
(0.031)\end{array}$ \\
\hline FAGDP $_{t-1}$ & $\begin{array}{r}0.000 \\
(0.000)\end{array}$ & $\begin{array}{r}0.000 \\
(0.000)\end{array}$ & $\begin{array}{r}0.000 \\
(0.000)\end{array}$ & $\begin{array}{r}0.000 \\
(0.000)\end{array}$ & $\begin{array}{r}0.000 \\
(0.000)\end{array}$ & $\begin{array}{r}0.000 \\
(0.000)\end{array}$ \\
\hline $\mathrm{GDP}_{\mathrm{t}-1}$ & $\begin{array}{r}0.000 * * * \\
(0.000)\end{array}$ & $\begin{array}{r}0.000 * * * \\
(0.000)\end{array}$ & $\begin{array}{r}0.000 \\
(0.000)\end{array}$ & $\begin{array}{r}0.000 * * * \\
(0.000)\end{array}$ & $\begin{array}{r}0.000 * * * \\
(0.000)\end{array}$ & $\begin{array}{r}0.000 \\
(0.000)\end{array}$ \\
\hline$\Delta \mathrm{GDP}_{\mathrm{t}-1}$ & $\begin{array}{r}-0.053 \\
(0.038)\end{array}$ & $\begin{array}{r}-0.056 \\
(0.038)\end{array}$ & $\begin{array}{r}-0.110 \\
(0.081)\end{array}$ & $\begin{array}{r}0.131^{* * * *} \\
(0.040)\end{array}$ & $\begin{array}{r}0.129 * * * \\
(0.041)\end{array}$ & $\begin{array}{r}0.123 \\
(0.083)\end{array}$ \\
\hline GOVGDP $_{\mathrm{t}-1}$ & $\begin{array}{r}0.001 \\
(0.001)\end{array}$ & $\begin{array}{r}0.001 \\
(0.001)\end{array}$ & $\begin{array}{r}0.001 \\
(0.001)\end{array}$ & $\begin{array}{r}0.000 \\
(0.001)\end{array}$ & $\begin{array}{r}0.000 \\
(0.001)\end{array}$ & $\begin{array}{r}0.000 \\
(0.001)\end{array}$ \\
\hline $\mathrm{INT}_{\mathrm{t}-1}$ & $\begin{array}{r}0.000 \\
(0.000)\end{array}$ & $\begin{array}{r}0.000 \\
(0.000)\end{array}$ & $\begin{array}{r}0.000 \\
(0.001)\end{array}$ & $\begin{array}{r}0.000 \\
(0.000)\end{array}$ & $\begin{array}{r}0.000 \\
(0.000)\end{array}$ & $\begin{array}{r}0.000 \\
(0.001)\end{array}$ \\
\hline INVGDP $_{\mathrm{t}-1}$ & $\begin{array}{r}0.000 \\
(0.000)\end{array}$ & $\begin{array}{r}0.000 \\
(0.000)\end{array}$ & $\begin{array}{r}0.000 \\
(0.001)\end{array}$ & $\begin{array}{r}-0.001 * * \\
(0.000)\end{array}$ & $\begin{array}{l}-0.001 * \\
(0.000)\end{array}$ & $\begin{array}{l}-0.001 \\
(0.001)\end{array}$ \\
\hline TRADE $_{t-1}$ & $\begin{array}{r}0.000 * * \\
(0.000)\end{array}$ & $\begin{array}{r}0.000 * * \\
(0.000)\end{array}$ & $\begin{array}{l}0.001 * \\
(0.000)\end{array}$ & $\begin{array}{r}0.000 * * \\
(0.000)\end{array}$ & $\begin{array}{r}0.000 * * \\
(0.000)\end{array}$ & $\begin{array}{r}0.000 * * \\
(0.000)\end{array}$ \\
\hline LNBANK $1_{t-1}$ & $\begin{array}{r}0.001 \\
(0.004)\end{array}$ & & & $\begin{array}{r}0.000 \\
(0.004)\end{array}$ & & \\
\hline LNBANK $2_{t-1}$ & & $\begin{array}{r}0.001 \\
(0.004)\end{array}$ & & & $\begin{array}{r}-0.001 \\
(0.004)\end{array}$ & \\
\hline LNBANK $3_{t-1}$ & & & $\begin{array}{r}0.008 \\
(0.010)\end{array}$ & & & $\begin{array}{r}0.005 \\
(0.011)\end{array}$ \\
\hline Country-fixed effects & Yes & Yes & Yes & Yes & Yes & Yes \\
\hline Year-fixed effects & Yes & Yes & Yes & Yes & Yes & Yes \\
\hline Adjusted $R^{2}$ & 0.012 & 0.012 & -0.020 & 0.088 & 0.087 & 0.076 \\
\hline F-statistic & $1.200 * *$ & $1.188 * *$ & 0.843 & $2.536 * * *$ & $2.512 * * *$ & $1.669 * * *$ \\
\hline Countries included & 150 & 150 & 140 & 149 & 149 & 139 \\
\hline Observations & 3,344 & 3,344 & 1,318 & 3,308 & 3,298 & 1,310 \\
\hline
\end{tabular}


Table 8: The effects of agricultural sector development and industrial sector development on banking sector development

This table presents the results of panel OLS regressions of the effects of agricultural sector development and industrial sector development on banking sector development during the period 1966-2016. The dependent variable is LNBANK1 (in columns (1) and (4)), LNBANK2 (in columns (2) and (5)) and LNBANK3 (in columns (3) and (6)). LNBANK1 is the natural logarithm of BANK1. LNBANK2 is the natural logarithm of BANK2. LNBANK3 is the natural logarithm of BANK3. Please see other variable definitions in Table 1. Country- and year-fixed effects are included in all models. Standard errors, which are reported in parentheses, are robust to heteroskedasticity and serial correlation and are clustered at the country level. Symbols ***,**, and * denote statistical significance at the $1 \%, 5 \%$ and $10 \%$ levels, respectively.

\begin{tabular}{|c|c|c|c|c|c|c|}
\hline \multirow[t]{2}{*}{ Variable } & (1) & (2) & (3) & (4) & (5) & (6) \\
\hline & LNBANK1 & LNBANK2 & LNBANK3 & LNBANK1 & LNBANK2 & LNBANK3 \\
\hline \multirow{3}{*}{$\begin{array}{l}\text { Lagged dependent } \\
\text { variable }\end{array}$} & & & & & & \\
\hline & & & & $0.852 * * *$ & $0.865 * * *$ & $0.803 * * *$ \\
\hline & & & & $(0.010)$ & (0.009) & (0.018) \\
\hline \multirow[t]{2}{*}{ FAGDP $_{\mathrm{t}-1}$} & $-0.003 * *$ & $-0.003 * *$ & 0.001 & 0.000 & 0.000 & 0.000 \\
\hline & $(0.001)$ & $(0.001)$ & $(0.001)$ & $(0.000)$ & $(0.000)$ & $(0.000)$ \\
\hline \multirow[t]{2}{*}{$\mathrm{GDP}_{\mathrm{t}-1}$} & 0.000 & 0.000 & $0.000^{* *}$ & 0.000 & 0.000 & $0.000^{*}$ \\
\hline & $(0.000)$ & $(0.000)$ & $(0.000)$ & $(0.000)$ & $(0.000)$ & $(0.000)$ \\
\hline \multirow{2}{*}{$\Delta \mathrm{GDP}_{\mathrm{t}-1}$} & 0.120 & 0.210 & $0.670 * * *$ & $0.432 * * *$ & $0.474 * * *$ & 0.202 \\
\hline & $(0.205)$ & $(0.205)$ & $(0.213)$ & $(0.082)$ & $(0.078)$ & (0.093) \\
\hline \multirow[t]{2}{*}{ GOVGDP $_{t-1}$} & $0.017 * *$ & $0.015 * * *$ & 0.010 & 0.001 & 0.000 & 0.003 \\
\hline & $(0.005)$ & $(0.005)$ & $(0.006)$ & $(0.001)$ & $(0.001)$ & $(0.002)$ \\
\hline \multirow[t]{2}{*}{$\mathrm{INT}_{\mathrm{t}-1}$} & 0.002 & 0.002 & -0.002 & 0.000 & 0.000 & $-0.002 * *$ \\
\hline & $(0.002)$ & $(0.002)$ & $(0.002)$ & $(0.001)$ & $(0.001)$ & $(0.001)$ \\
\hline \multirow[t]{2}{*}{ INVGDP $_{\mathrm{t}-1}$} & $0.013 * * *$ & $0.013 * * *$ & $0.008 * * *$ & $0.003 * * *$ & $0.003 * * *$ & 0.002 \\
\hline & $(0.003)$ & (0.003) & $(0.003)$ & $(0.001)$ & $(0.001)$ & $(0.001)$ \\
\hline \multirow[t]{2}{*}{ TRADE $_{\mathrm{t}-1}$} & 0.002 & 0.002 & -0.001 & 0.000 & 0.000 & -0.001 \\
\hline & $(0.001)$ & $(0.001)$ & $(0.001)$ & $(0.000)$ & $(0.000)$ & $(0.000)$ \\
\hline \multirow[t]{2}{*}{ LNAGRDEV $_{\mathrm{t}-1}$} & $-0.359 * * *$ & $-0.353 * * *$ & -0.097 & $-0.046 * * *$ & $-0.043^{* * *}$ & 0.018 \\
\hline & $(0.071)$ & $(0.071)$ & $(0.089)$ & (0.017) & (0.016) & $(0.028)$ \\
\hline \multirow{2}{*}{ LNINDDEV $_{\mathrm{t}-1}$} & -0.032 & 0.006 & 0.172 & $0.050 * *$ & $0.051 * *$ & 0.044 \\
\hline & $(0.094)$ & $(0.095)$ & $(0.110)$ & $(0.023)$ & $(0.023)$ & $(0.040)$ \\
\hline Country-fixed effects & Yes & Yes & Yes & Yes & Yes & Yes \\
\hline Year-fixed effects & Yes & Yes & Yes & Yes & Yes & Yes \\
\hline Adjusted $R^{2}$ & 0.855 & 0.855 & 0.967 & 0.963 & 0.967 & 0.992 \\
\hline F-statistic & $92.721 * * *$ & $92.900 * * *$ & $238.804 * * *$ & $409.870 * * *$ & $456.590 * * *$ & $886.575 * * *$ \\
\hline Countries included & 156 & 156 & 145 & 156 & 156 & 144 \\
\hline Observations & 3,340 & 3,333 & 1,354 & 3,337 & 3,329 & 1,231 \\
\hline
\end{tabular}


Table 9: The effects of agricultural sector growth and industrial sector growth on banking sector development

This table presents the results of panel OLS regressions of the effects of economic structure and growth on banking sector development during the period 1966-2016. The dependent variable is LNBANK1 (in columns (1) and (2)), LNBANK2 (in columns (3) and (4)) and LNBANK3 (in columns (5) and (6)). LNBANK1 is the natural logarithm of BANK1. LNBANK2 is the natural logarithm of BANK2. LNBANK3 is the natural logarithm of BANK3. Please see other variable definitions in Table 1. Country- and year-fixed effects are included in all models. Standard errors, which are reported in parentheses, are robust to heteroskedasticity and serial correlation and are clustered at the country level. Symbols ***, $* *$, and * denote statistical significance at the $1 \%, 5 \%$ and $10 \%$ levels, respectively.

\begin{tabular}{|c|c|c|c|c|c|c|}
\hline \multirow[t]{2}{*}{ Variable } & (1) & (2) & (3) & (4) & $(5)$ & (6) \\
\hline & LNBANK1 & LNBANK1 & LNBANK2 & LNBANK2 & LNBANK3 & LNBANK3 \\
\hline \multirow{3}{*}{$\begin{array}{l}\text { Lagged dependent } \\
\text { variable }\end{array}$} & & & & & & \\
\hline & $0.852 * * *$ & $0.847 * * *$ & $0.866^{* * *}$ & $0.861 * * *$ & $0.804 * * *$ & $0.797 * * *$ \\
\hline & (0.010) & (0.011) & (0.010) & (0.010) & (0.019) & (0.019) \\
\hline \multirow[t]{2}{*}{ FAGDP $_{\mathrm{t}-1}$} & 0.000 & 0.000 & 0.000 & 0.000 & 0.000 & 0.000 \\
\hline & $(0.000)$ & $(0.000)$ & $(0.000)$ & $(0.000)$ & $(0.001)$ & $(0.000)$ \\
\hline \multirow[t]{2}{*}{$\mathrm{GDP}_{\mathrm{t}-1}$} & 0.000 & 0.000 & 0.000 & 0.000 & $0.000 *$ & 0.000 \\
\hline & $(0.000)$ & $(0.000)$ & $(0.000)$ & $(0.000)$ & $(0.000)$ & $(0.000)$ \\
\hline \multirow[t]{2}{*}{$\Delta \mathrm{GDP}_{\mathrm{t}-1}$} & $0.227 * *$ & $0.208 *$ & $0.207 * *$ & $0.192 *$ & $0.368 * * *$ & $0.395 * * *$ \\
\hline & $(0.106)$ & $(0.111)$ & $(0.105)$ & $(0.109)$ & $(0.127)$ & (0.127) \\
\hline \multirow[t]{2}{*}{ GOVGDP $_{\mathrm{t}-1}$} & 0.001 & 0.001 & 0.000 & 0.000 & 0.002 & 0.003 \\
\hline & $(0.001)$ & $(0.001)$ & $(0.001)$ & $(0.001)$ & $(0.002)$ & $(0.002)$ \\
\hline \multirow[t]{2}{*}{$\mathrm{INT}_{\mathrm{t}-1}$} & 0.000 & 0.000 & 0.001 & 0.001 & $-0.001 *$ & $-0.001 *$ \\
\hline & $(0.001)$ & $(0.001)$ & $(0.001)$ & $(0.001)$ & $(0.001)$ & $(0.001)$ \\
\hline \multirow[t]{2}{*}{$\operatorname{INVGDP}_{\mathrm{t}-1}$} & $0.004 * * *$ & $0.003 * * *$ & $0.003 * * *$ & $0.003 * * *$ & $0.002 *$ & $0.002 *$ \\
\hline & $(0.001)$ & $(0.001)$ & $(0.001)$ & (0.001) & $(0.001)$ & $(0.001)$ \\
\hline \multirow[t]{2}{*}{ TRADE $_{t-1}$} & 0.000 & 0.000 & 0.000 & 0.000 & 0.000 & $-0.001 *$ \\
\hline & $(0.000)$ & $(0.000)$ & $(0.000)$ & $(0.000)$ & $(0.000)$ & $(0.000)$ \\
\hline \multirow[t]{2}{*}{$\mathrm{LNAGRDEV}_{\mathrm{t}-1}$} & & $-0.048 * * *$ & & $-0.045^{* * *}$ & & 0.019 \\
\hline & & $(0.018)$ & & $(0.017)$ & & $(0.031)$ \\
\hline \multirow[t]{2}{*}{ LNINDDEV $_{\mathrm{t}-1}$} & & $0.056^{* *}$ & & $0.059 * *$ & & 0.078 \\
\hline & & $(0.026)$ & & $(0.025)$ & & $(0.048)$ \\
\hline \multirow[t]{2}{*}{$\Delta \mathrm{AGRSIZE}_{\mathrm{t}-1}$} & $0.158 * * *$ & $0.161 * * *$ & $0.146 * * *$ & $0.149 * * *$ & -0.031 & -0.038 \\
\hline & $(0.038)$ & $(0.040)$ & $(0.037)$ & $(0.038)$ & $(0.041)$ & $(0.041)$ \\
\hline \multirow[t]{2}{*}{$\Delta \mathrm{INDSIZE}_{\mathrm{t}-1}$} & $0.163 * * *$ & $0.152 * * *$ & $0.185^{* * *}$ & $0.172 * * *$ & $-0.080 *$ & $-0.117 * *$ \\
\hline & $(0.044)$ & $(0.045)$ & $(0.043)$ & $(0.044)$ & $(0.048)$ & (0.049) \\
\hline Country-fixed effects & Yes & Yes & Yes & Yes & Yes & Yes \\
\hline Year-fixed effects & Yes & Yes & Yes & Yes & Yes & Yes \\
\hline Adjusted $R^{2}$ & 0.961 & 0.962 & 0.965 & 0.966 & 0.991 & 0.991 \\
\hline F-statistic & $391.695 * * *$ & $376.932 * * *$ & $431.125 * * *$ & $419.093 * * *$ & $878.524 * * *$ & $855.857 * * *$ \\
\hline Countries included & 149 & 146 & 149 & 146 & 139 & 136 \\
\hline Observations & 3,274 & 3,096 & 3,271 & 3,093 & 1,221 & 1,183 \\
\hline
\end{tabular}

